ISSN: 2146-3042

DOI: $10.25095 /$ mufad.579728

\title{
İşletmelerin Dupont Karlılık Analiziyle Performansının Belirlenmesi: Borsa İstanbul İmalat Sektörü Örneği ${ }^{*}$
}

Fatma AKYÜZ**

Tolga YEŞIL ${ }^{* * *}$

Ebru KARA $^{* * * *}$

\section{$\ddot{O Z E T}$}

Issletmelerin performanslarının bir göstergesi olan finansal tabloların amacı, ekonomik karar veren finansal tablo kullanıcılarının (yöneticiler, yatırımcılar, borç verenler, devlet vs.) yararlanmaları için ișletmenin finansal durumu ve performansı hakkında gerçeğe dönük sağllklı bilgi sağlamaktadır. Dolayısıyla finansal tablo aracılığıyla yapılan mali analizler, işletmelerin içinde bulunduğu sektördeki genel durum dikkate alınarak, finansal tablo kullacılarına yönelik fayda sağlamaktadır. Bu noktada, işletmenin finansal durumuyla ilgili kararlar verilmesinde ve performans ölçütlerinin belirlenmesinde, mali analiz tekniklerinin önemi ortaya çımaktadır.

Bu çalışmada; mali analiz tekniklerinden birisi olan ve oran analizleri içerisinde bulunan Dupont Karlllık Analizi incelenmiştir. Çalışmada imalat sektöründe faaliyet gösteren 178 işletme ele alınmış olup, işletmelerin Dupont finansal analiz tekniğiyle 2015-2017 yılları arasındaki finansal performansları karlılık durumu dikkate alınarak sektörel açıdan analiz edilmiştir.

Anahtar Kelimeler: Imalat sektörü, Kamu Aydinlatma Platformu, Dupont Karlılık Analizi.

JEL Sinıflandırması: M40, G30, G10.

\section{Determination of Enterprises' Performance with Using Dupont Profitability Analysis:} A Case Stock Exchange Istanbul Manufacturing Sector

\section{ABSTRACT}

The financial statements that are indicative of the performance of the businesses provide true information about the financial status and performance of the entity for the benefit of users of the financial statements (managers, investors, lenders, government, etc.).Therefore, it is emphasized that the financial analyzes made through the financial statements allow for positive results considering the general situation in the sector in which the companies are located. At this point, the importance of financial analysis techniques arises when decisions about the financial status of the business are made and performance criteria are determined.

In this study; Dupont Profitability Analysis which is one of the financial analysis techniques and included in the ratio analysis is examined. In the study, 178 enterprises operating in the manufacturing sector were analyzed and it was aimed to analyze the financial performances of the enterprises between 2015-2017 with the Dupont financial analysis technique and to determine the best business and the most risky business on sectoral basis.

Keywords: Manufacturing sector, Public Disclosure Platform, Dupont Profitability Analysis.

Jel Classification: M40, G30, G10.

Makale Gönderim Tarihi: 30.11.2018

Makale Kabul Tarihi: 22.01.2019

Makale Türü: Araştırma makalesi

\footnotetext{
${ }^{*}$ Bu çalışma, $6{ }^{\text {th }}$ SCF International Conference on "Economic and Social Impacts of Globalization and Liberalization" isimli konferansta 11-13 Ekim 2018 tarihlerinde Antalya'da sözlü olarak sunulmuş tam metin bildirinin genişletilmiş halidir.

** Dr. Öğr. Üyesi, Uşak Üniversitesi, İktisadi ve İdari Bilimler Fakültesi, fatma.akyuz@usak.edu.tr, ORCID ID: 0000-0002-7309-1586.

*** Öğr. Gör. Dr., Uşak Üniversitesi, Banaz Meslek Yüksekokulu, tolga.yesil@usak.edu.tr, ORCID ID: 00000002-3751-5222.

**** Uşak Üniversitesi, Sosyal Bilimler Enstitüsü,ebru.kara64@ @otmail.com, ORCID ID: 0000-0001-6056-9184.
} 


\section{GÍRIŞ VE LITERATÜR}

Finansal analiz; işletmelerin geçmiş yıllarla finansal durumunun karşılaştırılması, işletmelerin sektördeki konumunun ve performanlarının belirlenmesi amacıyla yapılmaktadır. Finansal analizle mevcut durumu belirlenen işletmeler, diğer bir basamak olan finansal planlama aşamasına geçmektedirler. Mevcut durum sonrası geleceğe yönelik, işletmelerin misyonu ve vizyonu doğrultusunda yapılan finansal planlamalar sayesinde işletmenin yol haritası çizilebilmektedir. Bu çalışmada finansal performansın belirlenmesi amacıyla bir finansal analiz türü olan, Dupont analiz yöntemi kullanılmışıtır. Dupont analiz yöntemini esas alan literatürdeki bazı çalışmalar incelenmiştir.

Karaman vd. (2014) Ankara'da gerçekleştirilen Ulusal Aile Birliği Sempozyumunda, bir tarımsal kooperatifin, 2013 y1l mali tablolarına ait verilerini Dupont modelinde kullanarak, finansal durumunu incelemişlerdir. Araştırma sonucunda ilgili tarımsal kooperatifin aktif sermaye getiri oranını 0,23 düzeyinde, öz sermaye getiri oranını 0,33 düzeyinde hesaplanmış ve bu değerler araştırmacılar tarafindan yorumlanmıştır.

Chang vd. (2014) sağllk hizmetleri alanında faaliyet gösteren işletmelere yönelik Dupont Analizini modifiye ederek gerçekleştirmişlerdir. 1984-2010 periyodlarını kapsayan 1420 işletme araştırmanın örneklemini oluşturmaktadır. Araştırma sonucunda, finansal tablolardaki muhasebe veri temelli uyarıların sağlı hizmetleri işletmelerinin geleceği için önemli olduğunu belirtmişlerdir.

Koşan ve Karadeniz (2013) Türk imalat sektöründeki küçük, orta ve büyük işletmelerin 2009-2010-2011 yıllarına ait finansal performanslarını Dupont Analiziyle incelemişlerdir. DuPont Analizi için Türkiye Cumhuriyet Merkez Bankası sektör bilançolarından faydalanmışlardır. Analiz sonucunda büyük işletmelerin başarılı bir finansal performans1 olduğunu, orta büyüklükteki işletmelerin ise küçük işletmelere göre finansal performanslarının başarılı olduğu ve küçük işletmelerin aktiflerini verimsiz kullandıkları belirtilmiştir.

Sheela ve Karthikeyan (2012) Hindistan ilaç sanayiindeki; Cipla, Dr. Reddy'sLaboratories, Ranbaxy isimli üç ilaç işletmesinin 2003-2012 dönemlerine ait verilerini kullanarak finansal performanslarını ölçmek için Dupont Analizini uygulamışlardır. Araştırma sonucunda finansal performansı en yüksek değerden en düşük değere doğru işletmelerin sıralamasi; Cipla, Dr. Reddy's Laboratories, Ranbaxy Pharma ceutical olarak açıklanmıştır.

Baştürk (2004), Dupont Kontrol Sistemini Türkiye'deki sigorta sektörüne uygulayarak sigorta işletmelerinin performans ölçümünü gerçekleştirmiştir. 1997-2001 yılları aralığında hayat sigortası ve hayat sigortası dışında, ilgili yıllarda aktif olarak faaliyet gösteren bir işletmelerin finansal performansları Dupont Kontrol Sistemi ile belirlenmiştir. Araştırma sonucu olarak; hayat sigortası sektöründe faaliyet gösteren işletmelerin net kar marjının yüksekken, varlık karlılığı açısından ise hayat sigortası dışında faaliyet gösteren sigorta işletmelerine göre düşük olduğu tespit edilmiştir.

Melvin vd. (2004) bir çiftlik işletmesinin fiyat, üretim, karlılık, yatırım kararları, finansal performansının belirlenmesi amacıyla e-öğrenme yazılım aracı geliştirmiş̧lerdir. Bu 
yazılım aracını geliştirip test etmek için, bilgisayar destekli uygulama ile ilgili çiftlik işletmesi için DuPont karlılık analizi modeli kullanılmıştır.

\section{DUPONT ANALIZí}

Bir rasyo analizi olan DuPont analizi, Pierre DuPont tarafindan 1920 yılında General Motor işletmesinde bir yönetim muhasebesi tekniği olarak kullanmasından sonra popüler olmuştur (Curtis vd. 2015, 1211). DuPont analizinin de yer aldığ çeşitli finansal ve diğer performans ölçüm sistemleri literatürde bulunmaktadır. Bu performans ölçüm sistemleri Tablo 1'de gösterilmiştir.

Tablo 1. Performans Ölçüm Sistemleri

\begin{tabular}{|c|c|}
\hline Yöntem & Yöntemi Ortaya Koyan \\
\hline $\begin{array}{l}\text { Yatırımın Geri Dönüş Oranı } \\
\text { (Return on Investment - ROI) }\end{array}$ & Du'Pont, 1920’ler \\
\hline Sink ve Tuttle Modeli & Sink ve Tuttle, 1989 \\
\hline Marka Değerleme (BrandValuation) & \\
\hline Müşteri Değer Analizi (Customer Value Analysis) & \\
\hline $\begin{array}{l}\text { Paydaş Değer Analizi (Shareholder Value Analysis - } \\
\text { SVA) }\end{array}$ & Rappaport, 1997 \\
\hline $\begin{array}{lll}\text { Faaliyet Tabanlı } & \text { Maliyetleme } & \text { (Activity } \\
\text { BasedCosting) } & \end{array}$ & Jhonson ve Kaplan, 1987 \\
\hline $\begin{array}{l}\text { Ekonomik Katma Değer (Economic Value Added - } \\
\text { EVA) }\end{array}$ & SternSteward\&Co \\
\hline Performans Piramidi (PerformancePyramid) & Judson,1990; Lynch ve Cross, 1991 \\
\hline Performans Prizması (PerformancePrism) & Kennerly ve Neely, 2000 \\
\hline Kurumsal Karne (BalancedScorecard) & Kaplan ve Norton, 1992 \\
\hline Mükemmellik Modeli (EFQM) & Avrupa Kalite Derneği, 1992 \\
\hline $\begin{array}{lcc}\text { Performans } & \text { Ölçüm } & \text { Matrisi } \\
\text { (PerformanceMeasurementMatrix) } & \end{array}$ & Keeganv.d., 1989 \\
\hline $\begin{array}{lcc}\text { Performans } & \text { Ölçüm } & \text { Anketi } \\
\text { (PerformanceMeasurementQuestionnaire) } & \\
\end{array}$ & Dixonv.d., 1990 \\
\hline $\begin{array}{l}\begin{array}{l}\text { Dünya Çapında Üretim İçin } \\
\text { (PerformanceMeasurementfor }\end{array} \\
\text { Manufacturing) } \\
\end{array}$ & Maskell, 1991 \\
\hline $\begin{array}{l}\text { Dinamik Performans Yönetim } \quad \text { Sistemi } \\
\text { (DynamicPerformance Management Systems) }\end{array}$ & Bititci, 2000 \\
\hline $\begin{array}{l}\text { Bütünleştirilmiş Performans Yönetim Sistemi } \\
\text { (IntegratedPerformance Management System) }\end{array}$ & Bititci, 1994 \\
\hline Medori ve Steple Yap1s1 & Medori ve Steple, 2000 \\
\hline
\end{tabular}

Kaynak: Yüreğir ve Nakıboğlu (2007; 550)

İşletmelerde finansal planlama ve kontrol faaliyetleri için finansal tablolar analizi yapılmaktadır. Finansal tablolar analizi, bir işletmenin; likidite durumunu, faaliyetlerinin verimliliğini, finansal yapısı ve karlılık durumu hakkında bilgi vermektedir. Birden fazla finansal oranın bir araya getirilerek karlılık durumunu ölçen analizlerden bir tanesi de Dupont analizidir. Dupont analizi, bir işletmenin belirli dönemine ait finansal tablolarından elde edilen verilerin anlamlı ilişkiler ortaya koyacak şekilde, oranların hesaplanması sonucunda bu oranların öz kaynak karlılığına etkisini gösteren kontrol şemasıdır (Sayılgan, 2013; 167-205). 
Dupont analizi, varlık devir hızı (Asset Turnover-ATO) ve satışlar aracılığıyla ölçülen net kar marjını (Profit Margin-PM) birleştirip, bu oranlar arasındaki etkileşimin işletme karlılığına etkisini belirlemektedir (Soliman, 2004; 7). Varlık devir hızı ile net kar marjının çarpımı sonucunda varlıkların karlılık düzeyi hesaplanmaktadır. Varlık karlılığı ve karlılı̆̆ etkileyen bir başka etmen olan özsermaye karlıllğı hesaplanma formülleri şu şekildedir (Akgüç, 2013; 84-86):

$$
\begin{aligned}
& \text { VarlıkKarlılıkOranı }=\frac{\text { Satışlar }}{\text { Varlık Toplamı }} \times \frac{\text { Net Kar }}{\text { Satışlar }} \\
& \tilde{O}_{\text {zsermayeKarlllıkOranı }}=\frac{\text { VarlıkKarlllıkOranı }}{1-(\text { Yabanc } 1 \text { kaynaklar } / \text { Varlık Toplamı })}
\end{aligned}
$$

Aydın vd. (2010) DuPont analiz yönteminde özsermaye karlılı̆̆ hesaplanmasını aşağıdaki gibi formülüze etmişlerdir:

$$
\frac{\text { NetKar }}{\text { Net Satışlar }} x \frac{\text { Net Satışlar }}{\text { Aktif Toplamı }} X \frac{\text { Aktif Toplamı }}{\text { Özsermaye Toplamı }}
$$

\section{VERİ VE YÖNTEM}

Bu çalışmada, Borsa İstanbul 100 kapsamında imalat sektöründe faaliyet gösteren işletmelerin finansal verileri, Kamu Aydınlatma Platform'dan (KAP) sağlanmıştır. Çalışmada 2015-2016 ve 2017 yılları baz alınmış olup imalat sektörünün alt dalları 9 sinıfta ayrı ayrı değerlendirilmeye alınmıştır. Buna gore alt sektör olarak; Gıda, İçki ve Tütün, Dokuma-Giyim Eşyası ve Deri, Orman Ürünleri ve Mobilya, Kağıt ve Kağıt Ürünleri, Kimya Petrol, Kauçuk ve Plastik, Taş ve Toprağa Dayalı, Metal Ana Sanayi, Metal Eşya- Makina ve Gereç Yapımı, Diğer İmalat Sektörü olarak 9 sınıfa ayrılarak incelenmiştir. Bu 9 alt grupta incelenen işletmelerin sayıları ise Tablo 2'de sunulmuştur.

Tablo 2. Borsa İstanbul'da Faaliyet Gösteren İmalat Sektöründeki İşletme Sayıları

\begin{tabular}{|l|l|c|c|c|}
\cline { 2 - 4 } \multicolumn{1}{c|}{} & Sektör İsimleri & $\begin{array}{c}\text { Verilerine } \\
\text { Ulașılan İşletme } \\
\text { Sayıs }\end{array}$ & $\begin{array}{c}\text { Verilerine } \\
\text { Ulaşılamayan } \\
\text { İşletme Sayısı }\end{array}$ & $\begin{array}{c}\text { Toplam İşletme } \\
\text { Sayısı }\end{array}$ \\
\hline 1 & Gıda, İçki ve Tütün & 27 & 1 & 28 \\
\hline 2 & Dokuma-Giyim Eşyası ve Deri & 21 & 1 & 22 \\
\hline 3 & Orman Ürünleri ve Mobilya & 5 & 0 & 5 \\
\hline 4 & Kağıt ve Kağıt Ürünleri & 14 & 0 & 32 \\
\hline 5 & Kimya Petrol, Kauçuk ve Plastik & 32 & 0 & 27 \\
\hline 6 & Taş ve Toprağa Dayalı & 27 & 0 & 17 \\
\hline 7 & Metal Ana Sanayi & 17 & 0 & 32 \\
\hline 8 & Metal Eşya- Makin ve Gereç & 32 & 0 & 3 \\
\hline 9 & Yapımı & & 2 & 180 \\
\hline TOP̆ğ İmalat Sektörü & 178 & & \\
\hline
\end{tabular}

KAP'tan alınan finansal verilere göre Dupont karlılık analizi yapılırken 2 işletmenin finansal verilerine ulaşılamaması, işletmelerin artık faaliyet göstermemeleri veya çalışmanın ele alındığı dönemler itibariyle faaliyetlerine yeni başlamış olmalarından dolayı 2 işletmenin verilerine ulaşılamadığından analize dahil edilmemiştir. Bu noktada imalat sektöründe faaliyet gösteren işletmelerin bilanço ve gelir tablolarından net satışları, net karı, aktif ve özsermaye toplamı ele alınarak, aktif devir hızı, net kar marjı, aktif karlılığı, özsermeye karlılığı ve özsermaye çarpanı 2015- 
2016-2017 yılları için hesaplanmıştır. Hesaplamaların sonuçlarını içeren tablolar hazırlanmış ve çalışmanın ekler bölümünde sunulmuştur. Daha sonrasında Dupont analizi tekniğiyle aktif karlılığı (Return on Assets -ROA), özsermaye karlılığı (Return on Equity - ROE) ve satışların karlılığı (Return on Sales- ROS) yorumlanmaya çalışılmıştır.

\section{BULGULAR}

Çalışmanın bulgular kısmında Borsa İstanbul 100 endeksi imalat sektöründe işlem gören işletmelerin bulunduğu sektörlerin ortalamaları ve bu sektörlerde olumsuz değerlere sahip olan işletmeler açıklanmıştır. Analiz sonucunda olumsuz değerlere sahip olan işletmeler ayrıca faaliyet gösterdiği sektör ortalamalarına göre karşılaştırılmıştır. BIST 100 endeksi imalat sektöründe işlem gören sektörlerin ortalamaları Tablo 3 'te yer almaktadır.

Tablo 3'teki gıda, içki ve tütün imalatı alanında faaliyet gösteren işletmelerin 2015 yılı sektör ortalamas1; ROE değeri -0,21407, ROS değeri -0,02000, ROA değeri ise -0,01593'dir. Çalışmanın ekler bölümündeki Tablo 1'e göre; gıda, içki ve tütün alanında faaliyet gösteren işletmelerin 2015 yılına ait Dupont Analizi incelendiğinde ROE değerinin en düşük olduğu işletme -3,59'luk oranla Kerevitaş Gıda Maddeleri Sanayii ve Ticaret A.Ş. olduğu görülmüştür. Kerevitaş Gıda Maddeleri Sanayii ve Ticaret A.Ş.'nin \% $-0,22$ olarak gerçekleşen ROS değeri ise her 100TL'lik satışın 22 TL'sinin net zarar olarak işletmede kaldığ1 görülmüştür. Gıda, içki ve tütün alanında faaliyet gösteren işletmelerin 2015 yılında ROE değerinin en yüksek olduğu Tukaş Gıda Sanayi ve Ticaret A.Ş. ve Türk Tuborg Bira ve Malt Sanayi A.Ş.'nin 0,31 oranla aynı değere sahip olduğu görülmektedir. Türk Tuborg Bira ve Malt Sanayi A.Ş. de ise ROS değerinin 0,21 olarak gerçekleştiği gürülmüştür. Yani her 100 TL'lik satışın 21 TL'sinin net kar olarak işletmede kaldığı görülmüştür.

Tablo 3'teki gıda, içki ve tütün imalatı alanında faaliyet gösteren işletmelerin 2016 yılı sektör ortalaması; ROE değeri 0,07407, ROS değeri -0,03519, ROA değeri ise -0,00963'dir. 2016 yılı analiz sonuçlarına göre en düşük ROE değerine -0,33'lük değerle Pınar Su Sanayi ve Ticaret A.Ş. işletmesinin olduğu görülmüştür. Pınar Su Sanayi ve Ticaret A.Ş.'nin ROS değeri -0,13 olarak gerçekleşmiş olup, her 100 TL'lik satışın 13 TL'lik kısmının işletmede net zarar olarak gerçekleştiği tespit edilmiştir. Bilanço kalemleri olarak analiz edildiğinde özsermaye çarpanının 3,22 olarak bulunmuş olup, işletme finansal açıdan risklere karşı savunmasız olarak ifade edilebilir. Tablo 12'deki gıda, içki ve tütün alanında faaliyet gösteren işletmelerin 2017 yılı sektör ortalamas1; ROE değeri -0,01000, ROS değeri 0,14555, ROA değeri ise 0,01296'dir. 2017 yılı analiz sonuçlarına göre ise en düşük ROE değerine sahip olan işletmenin -0, 92'lik oranla Merko Gıda Sanayi ve Ticaret A.Ş.dir. ROE'yı oluşturan kalemler olarak ROA değerinin -0,14, özsermaye çarpanının 6,39 olarak gerçekleşmiştir. Aktif devir hızının 1,00 çıkmasının nedeni olarak ROA değerinin ROS değerine $(-0,15)$ yakın olması gösterilebilir. ROS değerinin $-0,15$ çıkmasının nedeni olarak satışların maliyeti, faaliyet giderleri ve diğer giderlerin yüksek çıkması söylebilir. 2017 yılında ROE değerinin 0,92 bir oranla yüksek çıkmasının nedeni olarak 2016 yılına gore ROA değerinin ve özsermaye çarpanının yüksek çıkması ileri sürülebilir. 
Tablo 3. Sektör Ortalamaları

\begin{tabular}{|c|c|c|c|c|c|c|c|c|c|}
\hline \multirow{2}{*}{ Sektör İsmi } & \multicolumn{3}{|c|}{2015 Yılı Sektör Ortalamaları } & \multicolumn{3}{|c|}{2016 Yılı Sektör Ortalamaları } & \multicolumn{3}{|c|}{2017 Yılı Sektör Ortalamaları } \\
\hline & ROS & ROA & ROE & ROS & ROA & ROE & ROS & ROA & ROE \\
\hline $\begin{array}{l}\text { Gıda, İçki ve } \\
\text { Tütün }\end{array}$ & $-0,02000$ & $-0,01593$ & $-0,21407$ & $-0,03519$ & $-0,00963$ & 0,07407 & 0,14555 & 0,01296 & $-0,01000$ \\
\hline $\begin{array}{l}\text { Dokuma, } \\
\text { Giyim Eşyasi } \\
\text { ve Deri }\end{array}$ & 0,00428 & 0,01761 & 0,00571 & $-0,03238$ & $-0,01619$ & $-0,09524$ & $-0,37650$ & 0,01550 & 0,02200 \\
\hline $\begin{array}{l}\text { Orman } \\
\text { Ürünleri ve } \\
\text { Mobilya }\end{array}$ & 0,00200 & 0,04400 & $-0,10200$ & $-0,03400$ & 0,01000 & $-0,32800$ & 0,01200 & 0,03800 & 0,04200 \\
\hline $\begin{array}{l}\text { Kağit ve Kağıt } \\
\text { Ürünleri, } \\
\text { Basım } \\
\text { Yayın } \\
\end{array}$ & 0,01285 & 0,00500 & $-0,12714$ & 0,04785 & 0,00642 & $-3,49000$ & 0,00857 & 0,01285 & $-0,00214$ \\
\hline $\begin{array}{lr}\text { Kimya, } & \text { Petrol } \\
\text { Kauçuk ve ve } \\
\text { Plastik Ürünler }\end{array}$ & 0,08812 & 0,07281 & 0,10812 & 0,07000 & 0,06187 & 0,07531 & 0,08093 & 0,07781 & 0,19562 \\
\hline $\begin{array}{l}\text { Taş ve Toprağa } \\
\text { Dayalı }\end{array}$ & 0,10814 & 0,08074 & 0,11592 & 0,09481 & 0,06481 & 0,09222 & 0,04740 & 0,05037 & 0,07629 \\
\hline $\begin{array}{ll}\text { Metal } & \text { Ana } \\
\text { Sanayi } & \end{array}$ & 0,00529 & 0,01176 & $-0,15588$ & 0,03647 & 0,01941 & 0,29176 & 0,04764 & 0,04764 & 0,22941 \\
\hline $\begin{array}{l}\text { Metal Eşya, } \\
\text { Makine ve } \\
\text { Gereç Yapım }\end{array}$ & 0,05531 & 1,07937 & 0,04500 & 0,04937 & 0,06031 & 0,07531 & 0,06093 & 0,07562 & 0,13687 \\
\hline $\begin{array}{l}\begin{array}{l}\text { Diğer } \\
\text { Sanayi }\end{array} \\
\text { İmalat }\end{array}$ & $-0,39000$ & 0,07000 & 0,16333 & $-0,0300$ & $-0,0300$ & $-0,17333$ & $-0,09333$ & 2,48666 & $-0,58667$ \\
\hline
\end{tabular}


Dokuma, giyim eşyasi ve deri imalatı alanında faaliyet gösteren işletmelerin 2015, 2016 ve 2017 yılına ait Dupont analiz sonuçları, çalışmanın ekler bölümündeki Tablo 2'de yer almaktadır. Çalışmanın ekler bölümünde bulunan Tablo 2' ye göre 2015 yılı ROS ve ROA değerleri en düşük olan işletme Diriteks Diriliş Tekstil San. ve Tic. A.Ş. iken, 2015 yılı ROE değeri en düşük olan işletme Söktaş Tekstil San. ve Tic. A.Ş.'dir. 2016 yılı ROS ve ROA değerleri en düşük olan işletme yine Diriteks Diriliş Tekstil San. ve Tic. A.Ş. iken, en düşük ROE değeri Yünsa Yünlü San. ve Tic. A.Ş.'ye aittir. 2017 yılı analiz sonuçlarına göre ise; en düşük ROS değeri Karsu Tekstil San. ve Tic. A.Ş. en düşük ROA ve ROE değerleri Söktaş Tekstil

San. ve Tic. A.Ş., işletmelerine ait sonuçlar çıkmıştır. Tablo 3'teki dokuma, giyim eşyasi ve deri imalatı alanı sektör ortalamaları ile Yünsa Yünlü San. ve Tic. A.Ş. değerleri incelendiğinde; 2015 yılında sektör ortalamasına göre yüksek, 2016 yılı sektör ortalamasına göre düşük, 2017 yılı sektör ortalamasına göre yüksek olarak bulunmuştur. Karsu Tekstil San. ve Tic. A.Ş ve Diriteks Diriliş Tekstil San. ve Tic. A.Ş. işletmelerinin ise değerleri sektör ortalamasına göre 2015, 2016 ve 2017 y1llarında düşük olduğu ilgili tablolardan anlaşılmaktadır.

Orman ürünleri ve mobilya sektöründeki imalat alanında faaliyet gösteren işletmelerin 2015, 2016 ve 2017 yılına ait Dupont Analiz sonuçları çalışmanın ekler bölümündeki Tablo 3 'te yer almaktadır. Ekler bölümündeki Tablo 3'e göre, 3 dönemdeki en düşük ROS değerleri Orma Orman Mahsulleri Integ. San. ve Tic. A.Ş.'ye ait rakamlar çıkmıştır. En düşük ROA değerlerine sahip işletme açısından; 2015 yılında Orma Orman Mahsulleri Integ. San. ve Tic. A.Ş. ve Doğtaş Kelebek Mobilya San. ve Tic. A.Ş., 2016 yılında Orma Orman Mahsulleri Integ. San. ve Tic. A.Ş. iken, 2017 yılı Yonga Mobilya San. ve Tic. A.Ş.'dir. Analiz sonucundaki en düşük ROE değerlerine sahip işletmeler açısından ise 2015 ve 2016 yıllarında Doğtaş Kelebek Mobilya San. ve Tic. A.Ş., 2017 yılında Orma Orman Mahsulleri Integ. San. ve Tic. A.Ş. ve Yonga Mobilya San. ve Tic. A.Ş.'dir. Genel olarak ekler bölümündeki Tablo 3 incelendiğinde, 3 dönemlik sonuçlara göre en düşük karlılık oranlarına sahip dikkat çeken işletme Orma Orman Mahsulleri Integ. San. ve Tic. A.Ş. olduğu söylenebilir. Tablo 3'teki orman ürünleri ve mobilya imalat sektörü ortalamalarına göre Orma Orman Mahsulleri Integ. San. ve Tic. A.Ş. işletmesi 2015, 2016 ve 2017 y1lları itibariyle düşük değerlere sahiptir. Yonga Mobilya San. ve Tic. A.Ş. ise 2015 ve 2016 yılları sektör ortalamaları üzerinde değerlere sahipken 2017 yılındaki değerleri ise sektör ortalamalarının altında kaldığı dikkat çekmektedir. Doğtaş Kelebek Mobilya San. ve Tic. A.Ş. işletmesinin 2017 yılı ROE değeri haricinde diğer değerleri sektör ortalamalarına göre düşük olduğu anlaşılmaktadır.

Kağit ve kağıt ürünleri, basım ve yayın imalatı alanında faaliyet gösteren işletmelerin 2015, 2016 ve 2017 yılına ait Dupont analiz sonuçları çalışmanın ekler bölümündeki Tablo 4'te yer almaktadır. Ekler bölümündeki Tablo 4'e göre 2015 yılı ROS, ROA ve ROE karlılık oranları en düşük olan işletme Viking Kağıt ve Selüloz A.Ş.'dir. 2016 yılı en düşük ROS karlılık oranına sahip işletme Hürriyet Gazete ve Matbaacılık A.Ş., en düşük ROA ve ROE karlılık oranına sahip işletme ise Viking Kağıt ve Selüloz A.Ş.'dir. 2017 yılı ROS, ROA ve ROE karlılık oranları en düşük olan işletme Hürriyet Gazete ve Matbaacılık A.Ş.'dir. Genel olarak ekler bölümündeki Tablo 4 incelendiğinde 2017 yılı ilgili sektördeki karlılık oranları rakiplerine kıyasla olumsuz olarak dikkat çeken işletme Hürriyet Gazete ve Matbaacılık A.Ş.'dir. Tablo 3'teki kağit ve kağıt ürünleri, basım ve yayın sektörü ortalamalarına göre, Hürriyet Gazete ve Matbaacılık A.Ş. işletmesinin 2016 yılı ROE değeri haricinde, diğer 
karlılık oranlarına ait değerleri düşük olarak hesaplanmıştır. Viking Kağıt ve Selüloz A.Ş. işletmesinin ise 2015,2016 ve 2017 yıllarına ait değerleri sektör ortalamasına göre düşük olarak ilgili tablolarda yer almaktadır.

Kimya, petrol, kauçuk ve plastik ürünler imalatı alanında faaliyet gösteren işletmelerin 2015, 2016 ve 2017 yılına ait Dupont analiz sonuçları çalışmanın ekler bölümündeki Tablo 5’te yer almaktadır. 2015 y1lında; en düşük ROS ve ROE değerlerine sahip olan işletme, Sanifoam Sünger San. ve Tic. A.Ş. iken en düşük ROA değerine sahip olan işletme Sekuro Plastik Ambalaj San. A.Ş. dir. 2016 yılında; en düşük ROS ve ROA değerleri Bogfaş Bandırma Gübre Fabrikaları A.Ş., en düşük ROE değeri ise Egeplast Plastik Tic. ve San. A.Ş. işletmelerine aittir. 2017 yılında ise en düşük değerler Atlantik Petrol Ürünleri Tic. Ve San. A.Ş.'e aittir. Tablo 3'teki kimya, petrol, kauçuk ve plastik ürünler imalatı sektör ortalamalarına göre; işletme Sekuro Plastik Ambalaj San. A.Ş., Atlantik Petrol Ürünleri Tic. Ve San. A.Ş. ve Sanifoam Sünger San. ve Tic. A.Ş. işletmelerine ait 2015, 2016 ve 2017 yıllarına ait değerleri düşük olarak ilgili tablolarda yer almaktadır. Egeplast Plastik Tic. ve San. A.Ş. işletmesinin sektör ortalamasına göre 2015 yılındaki tüm değerleri düşük, 2016 yllı ROE değeri haricindeki ROA ve ROS değerleri yüksek, 2017 yılında ise tüm değerleri yüksek olduğu tespit edilmiştir.

Taş ve toprağa dayalı imalat alanında faaliyet gösteren işletmelerin 2015, 2016 ve 2017 yllına ait Dupont analiz sonuçları çalışmanın ekler bölümündeki Tablo 6'da yer almaktadır. Ekler bölümündeki Tablo 6'ya göre 2015 yılı en düşük karllık oranlarına sahip işletme Doğusan Boru San. ve Tic. A.Ş.' dir. 2016 yllında en düşük ROS değerine sahip işletme Doğusan Boru San. ve Tic. A.Ş, en düşük ROA ve ROE değerine sahip olan işletme Denizli Cam San. ve Tic. A.Ş.' dir. 2017 yilında en düşük ROA değerine sahip işletme Afyon Çimento San. ve Tic. A.Ş. iken, en düşük ROA ve ROE değerlerine sahip olan işletme Niğbaş Niğde Beton San. ve Tic. A.Ş.'dir. Tablo 3'teki kimya, petrol, kauçuk ve plastik ürünler imalatı sektör ortalamalarına göre Denizli Cam San. ve Tic. A.Ş., Doğusan Boru San. ve Tic. A.Ş. ve Niğbaş Niğde Beton San. ve Tic. A.Ş. işletmelerine ait değerler karşılaştırıldığında, tüm yıllar itibariyle değerlerinin düşük olarak gerçekleştiği anlaşılmaktadır. Afyon Çimento San. ve Tic. A.Ş. ise sektör ortalamalarına göre 2015 ve 2016 yılları ROS değeri haricindeki diğer değerleri düşük, 2017 yılı tüm değerleri düşük olarak hesaplanmıştır.

Metal ana sanayi imalat alanında faaliyet gösteren işletmelerin 2015, 2016 ve 2017 yılına ait Dupont analiz sonuçları çalışmanın ekler bölümündeki Tablo 7'de yer almaktadır. Ekler bölümündeki Tablo 7'ye göre 3 dönemdeki en düşük ROS değerine sahip işletme Çemaş Döküm San. A.Ş.'dir. En düşük ROA değerine sahip işletme 2015 yılında Özbal Çelik Boru Taah. Proje San. ve Tic. A.Ş., 2016 yılında Çemaş Döküm San. A.Ş. ve Demisaş Döküm San. ve Tic. A.Ş., 2017 yılında Çemaş Döküm San. A.Ş.'dir. En düşük ROE değerine sahip işletme 2015 yılında Özbal Çelik Boru San. Tic. ve Taah. A.Ş., 2016 yllında Döktaş Dökümcülük Tic. ve San. A.Ş., 2017 yllında Çemaş Döküm San. A.Ş.'dir. Tablo 3'teki kimya, petrol, kauçuk ve plastik ürünler imalatı sektör ortalamalarına göre Çemaş Döküm San. A.Ş. işletmesinin 2015 yllı ROE değeri haricindeki diğer bütün değerleri düşüktür. Döktaş Dökümcülük Tic. ve San. A.Ş. ve Demisaş Döküm San. ve Tic. A.Ş. ş̧letmelerinin sektör ortalamalarına göre; 2015 yılına ait değerleri yüksek, diğer yıllardaki değerleri düşük olduğu çalışmanın ekler bölümündeki Tablo 7 ve sektör ortalamalarının yer aldığı Tablo 3 'ten anlaşılmaktadır. 
Metal eşya, makine ve gereç yapım imalat alanında faaliyet gösteren işletmelerin 2015, 2016 ve 2017 yılına ait Dupont Analiz sonuçları çalışmanın ekler bölümündeki Tablo 8'de yer almaktadır. Ekler bölümündeki Tablo 8'e göre 2015 yılında en düşük ROS değerine sahip işletme Makina Takım Endüstrisi A.Ş., en düşük ROA ve ROE değerine sahip işletme Eminiş Ambalaj San. ve Tic. A.Ş.'dir. 2016 yılındaki en düşük karlılık oranlarına sahip işletme Eminiş Ambalaj San. ve Tic. A.Ş.'dir. 2017 yılında en düşük ROS değerine sahip işletme Emek Elektrik Endüstrisi A.Ş., en düşük ROA ve ROE değerine sahip işletme Eminiş Ambalaj San. ve Tic. A.Ş.'dir. Tablo 3'teki kimya, petrol, kauçuk ve plastik ürünler imalatı sektörü ortalamalarına göre Eminiş Ambalaj San. ve Tic. A.Ş. ve Emek Elektrik Endüstrisi A.Ş. işletmelerin değerleri tüm dönemler itibariyle düşüktür. Ayrıca Eminiş Ambalaj San. ve Tic. A.Ş. işletmesinin analiz sonucundaki bütün değerleri negatif olarak çalışmanın ekler bölümündeki Tablo 8'de yer alması dikkat çekmektedir. Makina Takım Endüstrisi A.Ş. işletmesinin sektör ortalamasına göre 2015 yılı ROE değeri ve 2017 yılı ROS değeri dışındaki değerleri düşük olduğu ilgili tablolardan anlaşılmaktadır.

Son olarak diğer imalat sanayi alanında faaliyet gösteren işletmelerin 2015, 2016 ve 2017 yılına ait Dupont analizi çalışmanın ekler bölümündeki Tablo 9'da yer almaktadır. Ekler bölümündeki tablo 9'a göre 2015 yılında en düşük karlılık oranlarına sahip işletme Serve Kırtasiye San. ve Tic. A.Ş.' dir. 2016 yılında en düşük karlılık oranlarına sahip işletme ise Say Reklamcılık Yapı Dek. Proje Taah. San ve Tic. A.Ş.'dir. 2017 yılında en düşük karlılık oranlarına sahip işletme yine Serve Kırtasiye San. ve Tic. A.Ş.' dir. Tablo 3'teki kimya, petrol, kauçuk ve plastik ürünler sektörü ortalamalarına göre Serve Kırtasiye San. ve Tic. A.Ş. işletmesinin 2016 yılındaki değerleri yüksek, 2015 ve 2017 yılı değerleri düşük olarak gerçekleşmiştir. Say Reklamcılık Yapı Dek. Proje Taah. San ve Tic. A.Ş. işletmesinin ise 2015 yılı değerleri sektör ortalamalarına göre yüksek, 2016 y1lı değerleri sektör ortalamalarına göre düşük olarak hesaplanmıştır. Bu işletmenin 2017 yılı değerlerine ise KAP'tan ulaşılamadığı için sektör karşılaştırması yapılamamıştır.

\section{SONUÇ}

Finansal analiz, finansal tabloların mali oranlar ve göstergeler kullanılarak işletmelerin geleceği hakkında bir takım çıkarımlarda bulunulmasını sağlamaktadır. Birden fazla finansal oran kullanılarak işletmelerin karlılığını ölçen analizlerden birisi ise dupont analizidir. $\mathrm{Bu}$ çalışmada; imalat alanında faaliyet gösteren 9 farklı sektörün finansal performanslarını Dupont analiziyle inceleyerek, sektör olarak finansal performansları açısından farklılık olup olmadığını belirlenmeye çalışılmıştır. Bu noktada Kamu Aydınlatma Platformu'dan (KAP) alınan bilanço ve gelir tablolarıyla 2015-2016-2017 yılları arasındaki temel konsolide finansal tablolara ile dupont analizi yapılmaya çalışılmıştır. Sektör ortalamaları karşılaştırılmaları sonucunda, çalışmanın bulgular kısmındaki ilgili tablolar incelendiğinde olumsuz olarak dikkat çeken bazı işletmeleri şu şekilde sıralayabiliriz: Sanayi ve Ticaret A.Ş.

- Gıda, İçki ve Tütün İmalatı Alanında Faaliyet Gösteren İşletme: Kerevitaş Gıda

- Dokuma, Giyim Eşyasi ve Deri İmalatı Alanında Faaliyet Gösteren İşletmeler: Diriteks Diriliş Tekstil San. ve Tic. A.Ş., Söktaş Tekstil San. ve Tic. A.Ş.

- Orman Ürünleri ve Mobilya İmalatı Alanında Faaliyet Gösteren İşletmeler: Orma Orman Mahs. Integ. San. ve Tic. A.Ş., Doğtaş Kelebek San. ve Tic. A.Ş. 
- Kağit ve Kağıt Ürünleri, Basım ve Yayın İmalatı Alanında Faaliyet Gösteren İşletmeler: Viking Kağıt ve Selüloz, Hürriyet Gazetecilik ve Matbaacılık A.Ş.

- Kimya, Petrol Kauçuk ve Plastik Ürünler İmalatı Alanında Faaliyet Gösteren İşletmeler: Atlantik Petrol Ürünleri San. ve Tic. A.Ş., Bogfaş Bandırma Gübre Fabrikaları A.Ş., Sanifoam Sünger Sanayi ve Tic. A.Ş.

- Taş ve Toprağa Dayalı İmalat Alanında Faaliyet Gösteren İşletmeler: Doğusan Boru San. ve Tic. A.Ş. Afyon Çimento San. ve Tic. A.Ş., Denizli Cam San. ve Tic. A.Ş.

- $\quad$ Metal Ana Sanayi İmalat Alanında Faaliyet Gösteren İşletmeler: Çemaş Döküm San. ve Tic. A.Ş.

- Metal Eşya, Makine ve Gereç Yapım Alanında Faaliyet Gösteren İşletmeler: Eminiş Ambalaj San. ve Tic. A.Ş.

- $\quad$ Diğer İmalat Sanayi Alanında Faaliyet Gösteren İşletmeler: Serve Kırtasiye San. ve Tic. A.Ş., Say Reklamcılık Yapı ve Dekorasyon Proje Taah.San. ve Tic. A.Ş.

Analiz sonucunda Gıda İçki ve Tütün sektöründe satış karlılığını gösteren Net Kar Marj1 (ROS) değerinin 2015-2016 yılında genelde düşük, 2017 yılında ise çalışmada ele alınan diğer yıllara gore biraz yükseldiği görülmüştür. Aktif karlılığı açısından ise genelde 2015 yılında eksi değerlerde olan işletmelerin, 2016 ve 2017 yılındaki oranlarının yükselişe geçtiği görülmüştür. Bu durum işletmelerin aktiflerini (varlıklarını) 2016 ve 2017 yıllarında daha verimli kullandıklarının bir göstergesi olarak ifade edilebilir.

İşletmelerin özsermaye karlılıklarını arttırabilmeleri için daha fazla finansal kaldıraçdan yararlanmaları gerekmektedir. Elbetteki finansal kaldıraç oranının yüksek olması, geri ödeme risk düzeyinin doğru tahmin edilmesi, işletmelerin ROS değerleri açısından son derece önemlidir. Sektörde faaliyet gösteren işletmelerin ithalat ve ihracat alanında da faaliyet göstermeleri ve döviz kurlarındaki dalgalanmalar ROS değerinin daha da düşük çıkmasının nedeni olarak gösterilebilir.

Günümüzde bazı işletmeler yabancı kaynak kullanımını yüksek düzeyde tutarak özkaynak kullanımını düşük düzeyde tutup, özsermeye karlılığını artırmak yolunu tercih etmektedirler. Ancak bu durum işletmeler için geri ödemede risk oluşturacağından ve faizanapara ödemesinde sıkıntıya düşmelerine neden olacağından yabancı kaynak kullanımından doğan borcu bir başka borçlanma ile kapatmayı tercih etmelerine neden olmaktadır. Bu durum yabancı kaynak kullanımıyla doğan borç yükünü daha da artmasına neden olmaktadır.

Bu noktada işletmelerin büyüklükleri ne olursa olsun, katlanılan maliyet ve giderlerin yükseliği, işletmelerdeki üretim kalitesinin düşmesine neden olabilmektedir. İşletmelerde hammmadde maliyeti, satış maliyeti, yönetim maliyeti ve üretim maliyeti önemli bir maliyet unsurudur. Bunun yanısıra döviz kurlarındaki dalgalanmalarda işletmeleri beklenmedik risklerle karşı karşıya bırakabilmektedir. Bunun için riskten korunma politikalarının, proaktif işletme yönetimi açısından önceden belirlenmesi önemlidir. 


\section{KAYNAKLAR}

Akgüç, Öztin (2013), Finansal Yönetim, 9. Baskı, Avcıl Basım Yayın, Ankara, Türkiye.

Aydin, Nurhan - Başar, Mehmet - Çoşkun, Metin, (2010), Finansal Yönetim, Detay Yayınc1lık, Ankara.

Baştürk, Feride. H. (2004), "Dupont Kontrol Sisteminin (DKS) Sigorta Şirketlerinin Performans Ölçümüne Uyarlanması”, İktisat, İşletme ve Finans, 19(220), ss.100-114.

Chang, Kathryn. J. - Chichernea, Doina. C. - HassabElnaby., Hassan R. (2014), "On the DuPont Analysis in the Health Care Industry", Journal Account Public Policy, 33, pp.83-103.

Christina Sheela, S. - Karthikeyan, K. (2012), "Financial Performance of Pharmaceutical Industry in India Using DuPont Analysis", European Journal of Business and Management, 4(14), pp.84-91.

Curtis, Asher - Lewis-Western, Melissa. F. - Toynbee, Sara (2015), "Historical Cost Measurement and the use of DuPont Analysis by Market Participants", Review of Accounting Studies, 20 (3), pp.1210-1245.

Karaman, Süleyman - Özalp, Asaf - Yilmaz, İbrahim (2014), “Tarımsal Kalkınma Kooperatif Karlılığının DuPont Model Analizi”, Ulusal Aile Çiftçiliği Sempozyumu, 30-31 Ekim 2014, Ankara, ss.73-78.

Koşan, Levent - Karadeniz, Erdinç (2013), “Türk İmalat Sektöründe Küçük, Orta ve Büyük Ölçekli İşletmelerin Finansal Performansının Dupont Analiz Tekniğiyle İncelenmesi”, Çağ Üniversitesi Sosyal Bilimler Dergisi, 10(2), ss.45-62.

Melvin, Jon - Boehlje, Michael - Dobbins, Craig - Gray, Allan (2004), "The DuPont Profitability Analysis Model: An Application and Evaluation of an E-Learning Tool”, Agricultural Finance Review, Spring, pp.75-89.

Sayılgan, Güven (2013), "Soru ve Yanıtlarıyla İşletme Finansmanı", Turhan Kitabevi, 6. Bas1, Ekim 2013, Ankara, Türkiye.

Soliman, Mark., T. (2004), "Using Industry-Adjusted DuPont Analysis to Predict Future Profitability", Working paper, Stanford University.

Yüreğir, Oya. H. - Nakıboğlu, Gülsün (2007), "Performans Ölçümü Ve Ölçüm Sistemleri: Genel Bir Bakış", Ç.Ü. Sosyal Bilimler Enstitüsü Dergisi, 16(2), ss.545-562. 


\section{EKLER}

Tablo 1. Gıda, İçki ve Tütün İmalatı Alanında Faaliyet Gösteren İşletmelerin 2015-2016-2017 Yılları Dupont Analizi

\begin{tabular}{|c|c|c|c|c|c|c|c|c|c|c|c|c|c|c|c|}
\hline \multirow[t]{2}{*}{ İşletme İsmi } & \multicolumn{5}{|c|}{2015} & \multicolumn{5}{|c|}{2016} & \multicolumn{5}{|c|}{2017} \\
\hline & $\begin{array}{l}\text { Net Kar } \\
\text { Marj1 } \\
\text { (ROS) }\end{array}$ & \begin{tabular}{|l|} 
Aktif \\
Devir Hızı
\end{tabular} & $\begin{array}{l}\text { Aktif } \\
\text { Karlılığ1 } \\
\text { (ROA) }\end{array}$ & $\begin{array}{l}\text { Özsermaye } \\
\text { Çarpanı }\end{array}$ & $\begin{array}{l}\text { Özsermaye } \\
\text { Karlılı̆̆1 } \\
\text { (ROE) }\end{array}$ & $\begin{array}{l}\text { Net Kar } \\
\text { Marj1 } \\
\text { (ROS) }\end{array}$ & $\begin{array}{l}\text { Aktif } \\
\text { Devir } \\
\text { Hızı }\end{array}$ & $\begin{array}{l}\text { Aktif } \\
\text { Karlı11ığ } \\
\text { (ROA) }\end{array}$ & $\begin{array}{l}\text { Özsemaye } \\
\text { Çarpanı }\end{array}$ & \begin{tabular}{|l} 
Özsermaye \\
Karlılığ1 \\
(ROE)
\end{tabular} & $\begin{array}{l}\text { Net Kar } \\
\text { Marj1 } \\
\text { (ROS) }\end{array}$ & $\begin{array}{l}\text { Aktif } \\
\text { Devir } \\
\text { Hiz1 }\end{array}$ & $\begin{array}{l}\text { Aktif } \\
\text { Karl1l1 } \breve{g}_{1} \\
\text { (ROA) }\end{array}$ & $\begin{array}{l}\text { Özsermaye } \\
\text { Çarpani }\end{array}$ & $\begin{array}{l}\text { Özsermaye } \\
\text { Karlılığ1 } \\
\text { (ROE) }\end{array}$ \\
\hline AltinYağ Kombinaları A.Ș. & $-0,06$ & 0,55 & $-0,33$ & 2,34 & $-0,07$ & $-0,06$ & 0,92 & $-0,06$ & 3,32 & $-0,19$ & $-0,02$ & 1,14 & $-0,03$ & 18,24 & $-0,47$ \\
\hline $\begin{array}{l}\text { Anadolu Efes Biracillk ve } \\
\text { Malt Sanavi A.S. }\end{array}$ & $-0,02$ & 0,46 & $-0,01$ & 1,75 & $-0,02$ & $-0,01$ & 0,41 & 0,00 & 1,73 & 0,00 & 0,01 & 0,44 & 0,01 & 1,88 & 0,01 \\
\hline $\begin{array}{l}\text { AVOD Kurutulmuş Gıda ve } \\
\text { Tarım Ürünleri A.Ș. }\end{array}$ & 0,02 & 0,80 & 0,02 & 1,87 & 0,03 & 0,00 & 0,67 & 0,00 & 1,60 & 0,00 & 0,00 & 0,65 & 0,00 & 1,82 & 0,00 \\
\hline $\begin{array}{l}\text { Banvit Bandırma Vitaminli } \\
\text { Yem Sanayi A.Ş. }\end{array}$ & $-0,05$ & 1,90 & $-0,09$ & 4,80 & $-0,46$ & 0,03 & 1,74 & 0,06 & 3,25 & 0,18 & 0,10 & 1,89 & 0,19 & 2,18 & 0,41 \\
\hline Coca-Cola İçecek A.ş. & 0,02 & 0,75 & 0,01 & 2,16 & 0,03 & 0,00 & 0,67 & 0,00 & 2,09 & $-0,01$ & 0,03 & 0,64 & 0,02 & 2,46 & 0,04 \\
\hline $\begin{array}{l}\text { Dardanel Önentaş Gıda } \\
\text { Sanayi A.Ş. }\end{array}$ & $-0,11$ & 3,78 & $-0,43$ & $-0,34$ & 0,15 & $-0,09$ & 4,38 & $-0,41$ & $-0,29$ & 0,12 & $-0,08$ & 4,05 & $-0,34$ & $-0,29$ & 0,10 \\
\hline $\begin{array}{l}\text { Ekiz Kimya Sanayi ve } \\
\text { Ticaret A.Ș. }\end{array}$ & $-0,39$ & 0,30 & $-0,12$ & 20,63 & $-2,42$ & 0,27 & 0,34 & 0,09 & 7,25 & 0,67 & $-0,04$ & 0,65 & $-0,02$ & 4,91 & $-0,12$ \\
\hline $\begin{array}{l}\text { Ersu Meyve ve Gıda Sanayi } \\
\text { A.Ş. }\end{array}$ & $-0,06$ & 0,28 & $-0,02$ & 1,35 & $-0,02$ & 0,01 & 0,17 & 0,00 & 1,19 & 0,00 & 0,13 & 0,18 & 0,02 & 1,26 & 0,03 \\
\hline $\begin{array}{l}\text { Frigo-Pak Gıda Maddeleri } \\
\text { Sanayi ve Ticaret A.Ş. }\end{array}$ & $-0,12$ & 0,77 & $-0,09$ & 5,12 & $-0,47$ & $-0,04$ & 0,88 & $-0,04$ & 4,72 & \begin{tabular}{|l|}
$-0,19$ \\
\end{tabular} & 0,02 & 0,82 & 0,02 & 3,53 & 0,07 \\
\hline $\begin{array}{l}\text { Kent Gida Maddeleri Sanayii } \\
\text { ve Ticaret A.Ş. }\end{array}$ & 0,09 & 0,93 & 0,09 & 1,47 & 0,13 & $-0,01$ & 1,09 & $-0,02$ & 1,72 & $-0,03$ & 0,06 & 1,19 & 0,07 & 1,54 & 0,10 \\
\hline $\begin{array}{l}\text { Kerevitaş Gıda Sanayi ve } \\
\text { Ticaret A.Ș. }\end{array}$ & $-0,22$ & 0,58 & $-0,13$ & 27,84 & $-3,59$ & $-0,16$ & 0,76 & $-0,12$ & $-11,58$ & 1,41 & 0,02 & 0,71 & 0,02 & 4,47 & 0,07 \\
\hline $\begin{array}{l}\text { Konfrut Gida Sanayi ve } \\
\text { Ticaret A..S. }\end{array}$ & 0,13 & 0,75 & 0,10 & 1,13 & 0,11 & 0,22 & 0,51 & 0,11 & 1,25 & \begin{tabular}{|l|}
0,14 \\
\end{tabular} & 0,21 & 0,67 & 0,14 & 1,32 & 0,18 \\
\hline $\begin{array}{l}\text { Kristal Kola ve Meşrubat } \\
\text { Sanayi ve Ticaret A.Ş. }\end{array}$ & 0,03 & 0,94 & 0,02 & 1,27 & 0,03 & 0,03 & 1,13 & 0,03 & 1,38 & \begin{tabular}{|l|}
0,04 \\
\end{tabular} & 0,03 & 0,89 & 0,02 & 1,58 & 0,04 \\
\hline $\begin{array}{l}\text { Merko Gıda Sanayi ve } \\
\text { Ticaret A.Ş. }\end{array}$ & 0,01 & 0,86 & 0,01 & 3,14 & 0,02 & $-0,08$ & 0,77 & $-0,06$ & 3,72 & $-0,22$ & $-0,15$ & 1,00 & $-0,14$ & 6,39 & $-0,92$ \\
\hline Oylum Sınai Yatırımları A.Ș. & \begin{tabular}{c|c|}
$-0,04$ \\
\end{tabular} & 0,59 & $-0,02$ & 2,24 & $-0,05$ & $-0,04$ & 0,63 & $-0,03$ & 2,18 & $-0,06$ & $-0,04$ & 0,65 & $-0,03$ & 2,12 & $-0,06$ \\
\hline Penguen Gıda Sanayi A.Ș. & 0,04 & 0,55 & 0,02 & 3,25 & 0,06 & $\begin{array}{c}-0,09 \\
\end{array}$ & 0,60 & $-0,05$ & 4,18 & $-0,21$ & $-0,09$ & 0,74 & $-0,07$ & 6,15 & 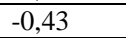 \\
\hline $\begin{array}{l}\text { Pinar Entegre Et ve Un } \\
\text { Sanayi A.Ş. }\end{array}$ & 0,11 & 1,13 & 0,13 & 1,28 & 0,16 & 0,09 & 1,17 & 0,11 & 1,31 & 0,14 & 0,09 & 1,00 & 0,09 & 1,30 & 0,12 \\
\hline & & & & & & & & & & & & & & & \\
\hline
\end{tabular}


Muhasebe ve Finansman Dergisi - Temmuz/2019

(83): $61-84$

\begin{tabular}{|c|c|c|c|c|c|c|c|c|c|c|c|c|c|c|c|}
\hline Pınar Su Sanayi ve Ticaret & $\overline{c-0,06}$ & $\begin{array}{l}0,97 \\
\end{array}$ & $\begin{array}{c}-0,06 \\
\end{array}$ & 2,78 & $\begin{array}{l}-0,17 \\
\end{array}$ & " $-0,13$ & $\bar{~} 0,80$ & $\begin{array}{l}-0,10 \\
\end{array}$ & 3,22 & $\overline{-0,33}$ & " $-0,10$ & $\bar{~} 0,80$ & $\begin{array}{c}-0,08 \\
\end{array}$ & 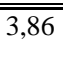 & $\overline{c-0,31}$ \\
\hline $\begin{array}{l}\text { Pinar Süt Mamulleri Sanayi } \\
\text { A.Ş. }\end{array}$ & $-0,06$ & 1,14 & 0,07 & 1,51 & 0,11 & 0,06 & 1,14 & 0,06 & 1,57 & 0,10 & 0,04 & 1,03 & 0,04 & 1,74 & 0,07 \\
\hline $\begin{array}{l}\text { Selçuk Gıda Endüstri İhracat } \\
\text { Itthalat A.Ș. }\end{array}$ & 0,10 & 0,48 & 0,05 & 1,53 & 0,07 & $-0,11$ & 0,45 & $-0,05$ & 1,73 & $-0,08$ & 0,03 & 0,67 & 0,02 & 1,63 & 0,03 \\
\hline Tat Gıda Sanayi A.Ș. & 0,07 & 1,39 & 0,10 & 1,56 & 0,16 & 0,07 & 1,42 & 0,09 & 1,50 & 0,14 & 0,06 & 1,37 & 0,08 & 1,59 & 0,12 \\
\hline $\begin{array}{l}\text { Taze Kuru Gıda Sanayi ve } \\
\text { Tİcaret A.Ș. }\end{array}$ & $-0,17$ & 0,75 & $-0,12$ & 2,89 & $-0,36$ & 0,02 & 0,72 & 0,01 & 2,30 & 0,03 & 0,03 & 0,48 & 0,01 & 3,07 & 0,04 \\
\hline $\begin{array}{l}\text { Tukaş Gida Sanayi ve Ticaret } \\
\text { A.S. }\end{array}$ & 0,23 & 0,60 & 0,14 & 2,24 & 0,31 & 0,08 & 0,69 & 0,05 & 2,16 & 0,11 & 0,03 & 0,64 & 0,02 & 2,62 & 0,04 \\
\hline $\begin{array}{l}\text { Türk Tuborg Bira ve Malt } \\
\text { Sanayi A.Ş. }\end{array}$ & 0,21 & 0,82 & 0,17 & 1,78 & 0,31 & 0,25 & 0,75 & 0,18 & 1,72 & 0,32 & 0,25 & 0,74 & 0,19 & 1,60 & 0,30 \\
\hline $\begin{array}{l}\text { Ulusoy Un Sanayi ve Ticaret } \\
\text { A.S. }\end{array}$ & 0,01 & 2,05 & 0,02 & 2,96 & 0,05 & 0,01 & 2,03 & 0,03 & 3,17 & 0,08 & 0,01 & 2,11 & 0,02 & 4,38 & 0,08 \\
\hline Ülker Bisküvi Sanayi A.Ș. & 0,08 & 0,78 & 0,07 & 2,40 & 0,16 & 0,06 & 0,71 & 0,04 & 2,98 & 0,12 & 0,08 & 0,58 & 0,05 & 3,09 & 0,14 \\
\hline $\begin{array}{l}\text { Vanet Gıda Sanayi İç veDış } \\
\text { Ticaret A.Ș. }\end{array}$ & $-0,33$ & 0,11 & $-0,03$ & 1,16 & $-0,04$ & $-1,33$ & 0,13 & $-0,18$ & 1,57 & $-0,28$ & 3,22 & 0,01 & 0,03 & 1,44 & 0,05 \\
\hline
\end{tabular}


Tablo 2. Dokuma, Giyim Eşyasi ve Deri İmalatı Alanında Faaliyet Gösteren İşletmelerin 2015-2016-2017 Yı1ları Dupont Analizi

\begin{tabular}{|c|c|c|c|c|c|c|c|c|c|c|c|c|c|c|c|}
\hline \multirow[t]{2}{*}{ İșletme İsmi } & \multicolumn{5}{|c|}{2015} & \multicolumn{5}{|c|}{2016} & \multicolumn{5}{|c|}{2017} \\
\hline & $\begin{array}{l}\text { Net } \\
\text { Kar } \\
\text { Marj1 } \\
\text { (ROS) }\end{array}$ & $\begin{array}{l}\text { Aktif } \\
\text { Devir } \\
\text { Hızı }\end{array}$ & $\begin{array}{l}\text { Aktif } \\
\text { Karlılı̆g1 } \\
\text { (ROA) }\end{array}$ & $\begin{array}{l}\text { Özsermaye } \\
\text { Çarpanı }\end{array}$ & $\begin{array}{l}\text { Özsermaye } \\
\text { Karlılığ } \\
\text { (ROE) }\end{array}$ & $\begin{array}{l}\text { Net } \\
\text { Kar } \\
\text { Marj1 } \\
\text { (ROS) }\end{array}$ & $\begin{array}{l}\text { Aktif } \\
\text { Devir } \\
\text { Hızı }\end{array}$ & $\begin{array}{l}\text { Aktif } \\
\text { Karlılığ1 } \\
\text { (ROA) }\end{array}$ & $\begin{array}{l}\text { Özsemaye } \\
\text { Çarpanı }\end{array}$ & $\begin{array}{l}\text { Özserma } \\
\text { ye } \\
\text { Karlılı̆ı } \\
\text { (ROE) }\end{array}$ & $\begin{array}{l}\text { Net } \\
\text { Kar } \\
\text { Marj1 } \\
\text { (ROS) }\end{array}$ & $\begin{array}{l}\text { Aktif } \\
\text { Devir } \\
\text { Hızi }\end{array}$ & $\begin{array}{l}\text { Aktif } \\
\text { Karlılığ } \\
\text { (ROA) }\end{array}$ & $\begin{array}{l}\text { Özsermaye } \\
\text { Çarpani }\end{array}$ & $\begin{array}{l}\text { Özsermaye } \\
\text { Karlılı̆g } 1 \\
\text { (ROE) }\end{array}$ \\
\hline Akin Tekstil A.S.S. & 0,52 & 0,35 & 0,18 & 1,18 & 0,22 & 0,03 & 0,38 & 0,01 & 1,17 & 0,01 & 0,03 & 0,39 & 0,01 & 1,32 & 0,02 \\
\hline $\begin{array}{l}\text { Arsan Tekstil Ticaret ve } \\
\text { Sanayi A.Ș. }\end{array}$ & 0,15 & 0,42 & 0,06 & 1,66 & \begin{tabular}{|l|}
0,11 \\
\end{tabular} & 0,09 & 0,47 & 0,04 & 1,61 & 0,07 & 0,19 & 0,51 & 0,09 & 1,56 & 0,15 \\
\hline $\begin{array}{l}\text { Bilici Yatırım Sanayi ve } \\
\text { Ticaret A.Ş. }\end{array}$ & 0,17 & 0,45 & 0,07 & 1,61 & 0,12 & 0,04 & 0,36 & 0,02 & 1,71 & 0,03 & 0,10 & 0,57 & 0,06 & 1,69 & 0,10 \\
\hline $\begin{array}{l}\text { Birko Birleşik } \\
\text { Koyunlulular Mensucat } \\
\text { Ticaret ve Sanayi A.Ş. }\end{array}$ & $-0,10$ & 0,53 & $-0,05$ & 2,66 & $-0,14$ & $-0,16$ & 0,51 & $-0,08$ & 2,32 & $-0,19$ & $-0,09$ & 0,18 & $-0,02$ & 1,80 & $-0,03$ \\
\hline $\begin{array}{l}\text { Birlik Mensucat Ticaret } \\
\text { ve Sanayi A.Ş. }\end{array}$ & $-0,55$ & 0,15 & $-0,08$ & 1,83 & $-0,15$ & $-0,50$ & 0,21 & $-0,10$ & 2,13 & $-0,22$ & $-0,32$ & 0,18 & $-0,06$ & 2,22 & $-0,13$ \\
\hline $\begin{array}{l}\text { Bossa Ticaret ve Sanayi } \\
\text { İșletmeleri A.Ș. }\end{array}$ & 0,06 & 0,55 & 0,03 & 2,23 & 0,07 & $-0,02$ & 0,50 & $-0,01$ & 2,41 & $-0,03$ & 0,02 & 0,69 & 0,01 & 8,79 & 0,13 \\
\hline $\begin{array}{l}\text { Dagi Giyim Sanayi ve } \\
\text { Ticaret A.Ş. }\end{array}$ & 0,04 & 0,81 & 0,03 & 1,95 & 0,06 & $-0,03$ & 0,47 & $-0,02$ & 1,43 & $-0,02$ & 0,00 & 0,57 & 0,00 & 1,53 & 0,00 \\
\hline $\begin{array}{l}\text { Derimod Konfeksiyon } \\
\text { Ayakkabı Deri Sanayi ve } \\
\text { Ticaret A.Ş. }\end{array}$ & 0,03 & 1,02 & 0,03 & 5,43 & 0,14 & 0,02 & 0,89 & 0,01 & 5,53 & 0,08 & 0,00 & 0,76 & 0,00 & 7,36 & 0,02 \\
\hline $\begin{array}{l}\text { Desa Deri Sanayi ve } \\
\text { Ticaret A.Ș. }\end{array}$ & $-0,02$ & 1,13 & $-0,02$ & 2,77 & $-0,06$ & $-0,09$ & 0,79 & $-0,07$ & 3,86 & $-0,27$ & 0,00 & 0,82 & 0,00 & 3,61 & 0,00 \\
\hline $\begin{array}{l}\text { Diriteks Diriliş Tekstil } \\
\text { Sanayi ve Ticaret A.Ș. }\end{array}$ & $\begin{array}{l}-0,74 \\
\end{array}$ & 0,15 & $-0,11$ & 1,90 & $-0,20$ & $-0,69$ & 0,30 & $-0,20$ & 2,65 & $-0,54$ & $-0,22$ & 0,25 & $-0,05$ & 1,89 & $-0,10$ \\
\hline $\begin{array}{l}\text { Hateks Hatay Tekstil } \\
\text { İşletmeleri A.Ş. }\end{array}$ & 0,02 & 0,73 & 0,02 & 1,74 & 0,03 & 0,15 & 0,36 & 0,05 & 1,52 & 0,08 & $-0,05$ & 0,60 & $-0,03$ & 1,55 & $-0,05$ \\
\hline $\begin{array}{l}\text { Karsu Tekstil Sanayi ve } \\
\text { Ticaret A.Ş. }\end{array}$ & $-0,10$ & 0,55 & $-0,05$ & 4,74 & $-0,26$ & $-0,07$ & 0,64 & $-0,05$ & 6,44 & $-0,30$ & $-7,62$ & 0,00 & $-0,02$ & 5,11 & $-0,08$ \\
\hline $\begin{array}{l}\text { Kordsa Teknik Tekstil } \\
\text { AȘ. }\end{array}$ & 0,06 & 0,80 & 0,05 & 1,79 & 0,08 & 0,07 & 0,75 & 0,06 & 1,73 & 0,10 & 0,07 & 0,87 & 0,06 & 1,74 & 0,10 \\
\hline $\begin{array}{l}\text { Lüks Kadife Ticaret ve } \\
\text { Sanayi A.Ş. }\end{array}$ & 0,06 & 0,31 & 0,02 & 1,82 & 0,04 & 0,50 & 0,21 & 0,10 & 1,74 & 0,18 & $-0,02$ & 0,32 & $-0,01$ & 1,79 & $-0,01$ \\
\hline $\begin{array}{l}\text { Menderes Tekstil Sanayi } \\
\text { ve Ticaret A.S.. }\end{array}$ & 0,05 & 0,75 & 0,04 & 2,54 & 0,10 & 0,00 & 0,77 & 0,00 & 3,00 & $-0,01$ & 0,07 & 0,72 & 0,05 & 3,46 & 0,16 \\
\hline $\begin{array}{l}\text { Rodrigo Tekstil Sanayi ve } \\
\text { Ticaret A A.Ş. }\end{array}$ & 0,01 & 0,70 & 0,01 & 1,93 & 0,02 & 0,00 & 0,53 & 0,00 & 2,09 & 0,00 & 0,01 & 0,64 & 0,00 & 2,37 & 0,01 \\
\hline & & & & & & & & & & & & & & & \\
\hline
\end{tabular}


Muhasebe ve Finansman Dergisi - Temmuz/2019

(83): $61-84$

\begin{tabular}{|c|c|c|c|c|c|c|c|c|c|c|c|c|c|c|c|}
\hline $\begin{array}{l}\text { Royal Halı İplik Tekstil } \\
\text { Mobilya Sanayi ve Ticaret } \\
\text { A.Ș. }\end{array}$ & 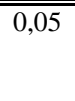 & 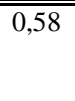 & 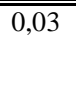 & 2,76 & 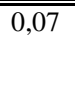 & "-0,16 & $0,0,46$ & "-0,07 & $\begin{array}{l}3,08 \\
\end{array}$ & 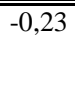 & " & "ב--- & ב---- & " & ב---- \\
\hline $\begin{array}{l}\text { Söktaş Tekstil Sanayi ve } \\
\text { Ticaret A.Ş. }\end{array}$ & $-0,11$ & 0,53 & $-0,06$ & 6,84 & $-0,41$ & $-0,12$ & 0,48 & $-0,06$ & 4,64 & $-0,26$ & $-0,14$ & 0,55 & $-0,07$ & 6,33 & $-0,47$ \\
\hline $\begin{array}{l}\text { Sönmez Pamuklu Sanayi } \\
\text { A.Ş. }\end{array}$ & 0,44 & 0,27 & 0,12 & 1,05 & 0,12 & 0,37 & 0,30 & 0,11 & 1,05 & 0,12 & 0,30 & 0,32 & 0,10 & 1,05 & 0,10 \\
\hline $\begin{array}{l}\text { Yataş Yatak ve Yorgan } \\
\text { Sanayi ve Ticaret A.S.S. }\end{array}$ & 0,03 & 1,10 & 0,03 & 3,29 & 0,10 & 0,03 & 1,44 & 0,05 & 3,26 & 0,16 & 0,09 & 1,47 & 0,13 & 2,30 & 0,29 \\
\hline $\begin{array}{l}\text { Yünsa Yünlü Sanayi ve } \\
\text { Ticaret A.Ș. }\end{array}$ & 0,02 & 0,92 & 0,02 & 3,41 & 0,06 & $-0,14$ & 0,97 & $-0,13$ & 5,65 & $-0,76$ & 0,05 & 1,21 & 0,06 & 3,75 & 0,23 \\
\hline
\end{tabular}

Tablo 3. Orman Ürünleri ve Mobilya İmalatı Alanında Faaliyet Gösteren İşletmelerin 2015-2016-2017 Y1lları Dupont Analizi

\begin{tabular}{|c|c|c|c|c|c|c|c|c|c|c|c|c|c|c|c|}
\hline \multirow[t]{2}{*}{ İșletme İsmi } & \multicolumn{5}{|c|}{2015} & \multicolumn{5}{|c|}{2016} & \multicolumn{5}{|c|}{2017} \\
\hline & $\begin{array}{l}\text { Net Kar } \\
\text { Marj1 } \\
\text { (ROS) }\end{array}$ & $\begin{array}{l}\text { Aktif } \\
\text { Devir } \\
\text { Hız1 }\end{array}$ & $\begin{array}{l}\text { Aktif } \\
\text { Karlılı̆g1 } \\
\text { (ROA) }\end{array}$ & $\begin{array}{l}\text { Özsermaye } \\
\text { Çarpanı }\end{array}$ & $\begin{array}{l}\text { Özsermaye } \\
\text { Karlılı̆ı } \\
\text { (ROE) }\end{array}$ & $\begin{array}{l}\text { Net Kar } \\
\text { Marj1 } \\
\text { (ROS) }\end{array}$ & $\begin{array}{l}\text { Aktif } \\
\text { Devir } \\
\text { Hizı }\end{array}$ & $\begin{array}{l}\text { Aktif } \\
\text { Karl1liğg } \\
\text { (ROA) }\end{array}$ & $\begin{array}{l}\text { Özssema } \\
\text { ye } \\
\text { Çarpanı }\end{array}$ & $\begin{array}{l}\text { Özsermaye } \\
\text { Karlılı̆̆1 } \\
\text { (ROE) }\end{array}$ & $\begin{array}{l}\text { Net Kar } \\
\text { Marj1 } \\
\text { (ROS) }\end{array}$ & $\begin{array}{l}\text { Aktif } \\
\text { Devir } \\
\text { Hzzı }\end{array}$ & $\begin{array}{l}\text { Aktif Karlılığ1 } \\
\text { (ROA) }\end{array}$ & $\begin{array}{l}\text { Özsermaye } \\
\text { Çarpani }\end{array}$ & $\begin{array}{l}\text { Özsermaye } \\
\text { Karl1l1 ğ } 1 \\
\text { (ROE) }\end{array}$ \\
\hline $\begin{array}{l}\text { Doğtaş Kelebek Mobilya } \\
\text { Sanayi ve Ticaret A.Ş. }\end{array}$ & $-0,07$ & 0,92 & $-0,07$ & 11,31 & $-0,77$ & $-0,10$ & 0,87 & $-0,09$ & 17,52 & $-1,53$ & 0,03 & 0,91 & 0,02 & 7,40 & 0,17 \\
\hline $\begin{array}{l}\text { Gentaş Genel Metal Sanayi ve } \\
\text { Ticaret A.Ș. }\end{array}$ & 0,05 & 0,86 & 0,04 & 1,34 & 0,06 & 0,08 & 0,87 & 0,07 & 1,46 & 0,11 & 0,1 & 0,91 & 0,09 & 1,51 & 0,13 \\
\hline $\begin{array}{l}\text { Orma Orman Mahsulleri } \\
\text { Integre Sanayi ve Ticaret A.S. }\end{array}$ & $-0,17$ & 0,45 & $-0,07$ & 3,78 & $-0,28$ & $-0,27$ & 0,43 & $-0,11$ & 5,08 & $-0,58$ & $-0,15$ & 0,41 & $-0,06$ & 4,86 & $-0,3$ \\
\hline $\begin{array}{l}\text { Sumas Suni Tahta ve } \\
\text { Mobilya Sanayi A.Ş. }\end{array}$ & 0,04 & 1,61 & 0,07 & 2,37 & 0,16 & 0,09 & 1,51 & 0,13 & 2,27 & 0,30 & 0,18 & 1,55 & 0,28 & 1,80 & 0,51 \\
\hline $\begin{array}{l}\text { Yonga Mobilya Sanayi ve } \\
\text { Ticaret A.S. }\end{array}$ & 0,16 & 1,55 & 0,25 & 1,26 & 0,32 & 0,03 & 1,52 & 0,05 & 1,34 & 0,06 & $-0,1$ & 1,38 & $-0,14$ & 2,13 & $-0,3$ \\
\hline
\end{tabular}


Tablo 4. Kağit ve Kağıt Ürünleri, Basım ve Yayın İmalat Alanında Faaliyet Gösteren İşletmelerin 2015-2016-2017 Y1lları Dupont Analizi

\begin{tabular}{|c|c|c|c|c|c|c|c|c|c|c|c|c|c|c|c|}
\hline \multirow[t]{2}{*}{ İşletme İsmi } & \multicolumn{5}{|c|}{2015} & \multicolumn{5}{|c|}{2016} & \multicolumn{5}{|c|}{2017} \\
\hline & $\begin{array}{l}\text { Net } \\
\text { Kar } \\
\text { Marj1 } \\
\text { (ROS) }\end{array}$ & $\begin{array}{l}\text { Aktif } \\
\text { Devir } \\
\text { Hızı }\end{array}$ & $\begin{array}{l}\text { Aktif } \\
\text { Karlılığ1 } \\
\text { (ROA) }\end{array}$ & $\begin{array}{l}\text { Özsermaye } \\
\text { Çarpanı }\end{array}$ & $\begin{array}{l}\text { Özsermaye } \\
\text { Karlılığ1 } \\
\text { (ROE) }\end{array}$ & $\begin{array}{l}\text { Net } \\
\text { Kar } \\
\text { Marj1 } \\
\text { (ROS) }\end{array}$ & $\begin{array}{l}\text { Aktif } \\
\text { Devir } \\
\text { Hizı }\end{array}$ & $\begin{array}{l}\text { Aktif } \\
\text { Karlılığ1 } \\
\text { (ROA) }\end{array}$ & $\begin{array}{l}\text { Özsemaye } \\
\text { Çarpanı }\end{array}$ & $\begin{array}{l}\text { Özsermaye } \\
\text { Karlılığı } \\
\text { (ROE) }\end{array}$ & $\begin{array}{l}\text { Net } \\
\text { Kar } \\
\text { Marj1 } \\
\text { (ROS) }\end{array}$ & $\begin{array}{l}\text { Aktif } \\
\text { Devir } \\
\text { Hizi }\end{array}$ & $\begin{array}{l}\text { Aktif } \\
\text { Karlılığ } \\
\text { (ROA) }\end{array}$ & $\begin{array}{l}\text { Özsermaye } \\
\text { Çarpani }\end{array}$ & $\begin{array}{l}\text { Özsermaye } \\
\text { Karlılığı } \\
\text { (ROE) }\end{array}$ \\
\hline $\begin{array}{l}\text { Alkim Kağıt Sanayi ve } \\
\text { Ticaret A.S. }\end{array}$ & 0,07 & 1,02 & 0,07 & 1,5 & 0,1 & 0,15 & 1,04 & 0,16 & 1,37 & 0,21 & 0,12 & 1,34 & 0,15 & 1,38 & 0,21 \\
\hline $\begin{array}{l}\text { Bak Ambalaj Sanayi ve } \\
\text { Ticaret A.Ş. }\end{array}$ & 0,01 & 1,04 & 0,01 & 2,41 & 0,02 & 0,35 & 0,09 & 0,03 & 2,70 & 0,09 & 0,09 & 0,94 & 0,08 & 2,64 & 0,22 \\
\hline $\begin{array}{l}\text { Demirören Gazetececilik } \\
\text { A.Ș. (doğan gazetecelik) }\end{array}$ & 0,32 & 0,43 & 0,14 & 1,11 & 0,15 & 0,46 & 0,38 & 0,18 & 1,11 & 0,20 & 0,22 & 0,37 & 0,08 & 1,13 & 0,09 \\
\hline $\begin{array}{l}\text { Doğan Burda Dergi } \\
\text { Yayıncilık ve Pazarlama }\end{array}$ & 0,04 & 1,6 & 0,06 & 1,75 & 0,1 & $-0,04$ & 1,65 & $-0,07$ & 2,04 & $-0,15$ & $-0,02$ & 1,57 & $-0,03$ & 2,21 & $-0,07$ \\
\hline $\begin{array}{l}\text { Duran Doğan Basım ve } \\
\text { Ambalaj Sanayi A.Ș. }\end{array}$ & $-0,11$ & 0,78 & $-0,08$ & 4,96 & $-0,42$ & 0,00 & 0,93 & 0,00 & 7,54 & 0,00 & 0,08 & 0,98 & 0,08 & 3,54 & 0,27 \\
\hline $\begin{array}{l}\text { Hürriyet Gazetecelik ve } \\
\text { Matbaacılık A.Ş. }\end{array}$ & $-0,05$ & 0,68 & $-0,03$ & 2,47 & $-0,09$ & $-0,13$ & 0,60 & $-0,08$ & 2,24 & $-0,17$ & $-0,49$ & 0,7 & $-0,34$ & 2,54 & $-0,87$ \\
\hline Ihlas Gazetecilik A.Ş. & $-0,03$ & 0,27 & $-0,01$ & 1,21 & $-0,01$ & $-0,02$ & 0,29 & 0,00 & 1,19 & $-0,01$ & $-0,02$ & 0,37 & $-0,01$ & 1,17 & $-0,01$ \\
\hline $\begin{array}{l}\text { Kaplamin Ambalaj Sanayi } \\
\text { Ve Ticaret A.Ş. }\end{array}$ & $-0,06$ & 1,55 & $-0,09$ & 5,15 & $-0,47$ & $-0,01$ & 1,46 & $-0,01$ & 5,31 & $-0,05$ & 0,06 & 1,07 & 0,06 & 3,04 & 0,19 \\
\hline $\begin{array}{l}\text { Kortonsan Karton Sanayi } \\
\text { ve Ticaret A.Ş. }\end{array}$ & 0,08 & 0,75 & 0,06 & 1,28 & 0,08 & 0,01 & 0,91 & 0,01 & 1,24 & 0,01 & 0,08 & 1,28 & 0,1 & 1,2 & 0,12 \\
\hline $\begin{array}{l}\text { Mondi Tire Kutsan Kağıt } \\
\text { ve Ambalaj Sanayi A.Ș. }\end{array}$ & 0 & 1,16 & 0 & 2,51 & 0,01 & 0,00 & 1,03 & 0,00 & 2,98 & 0,01 & 0,03 & 1,18 & 0,03 & 3,4 & 0,12 \\
\hline $\begin{array}{l}\text { Olmuksan International } \\
\text { Paper Ambalaj Sanayi ve } \\
\text { Ticaret A.Ș. }\end{array}$ & 0,01 & 1,2 & 0,02 & 1,68 & 0,03 & $-0,02$ & 1,32 & $-0,03$ & 1,86 & $-0,06$ & 0,01 & 1,33 & 0,02 & 2,5 & 0,04 \\
\hline $\begin{array}{l}\text { Prizma Pres Matbaacılık } \\
\text { Yayıncılık Sanayi ve } \\
\text { Ticaret A.Ș. }\end{array}$ & 0,06 & 0,43 & 0,03 & 1,06 & 0,03 & 0,06 & 0,32 & 0,02 & 1,09 & 0,02 & 0,01 & 0,39 & 0 & 1,14 & 0 \\
\hline $\begin{array}{l}\text { Saray Matbaacilık } \\
\text { Kağitçıllk Kırtasiyecilik } \\
\text { Ticaret ve Sanayi AŞ. }\end{array}$ & 0,01 & 0,83 & 0,01 & 3,22 & 0,02 & $\begin{array}{l}-0,04 \\
\end{array}$ & 0,90 & $\begin{array}{l}-0,03 \\
\end{array}$ & 3,38 & $-0,11$ & 0,04 & 0,68 & 0,03 & 3,81 & 0,11 \\
\hline Viking Kağıt ve Selüloz & $-0,17$ & 0,75 & $-0,12$ & 10,73 & $-1,33$ & $-0,10$ & 0,90 & $-0,09$ & 555,87 & $-48,85$ & $-0,09$ & 0,78 & $\begin{array}{l}-0,07 \\
\end{array}$ & 6,6 & $-0,45$ \\
\hline
\end{tabular}


Tablo 5. Kimya, Petrol Kauçuk ve Plastik Ürünler İmalat Alanında Faaliyet Gösteren İşletmelerin 2015-2016-2017 Y1lları Dupont Analizi

\begin{tabular}{|c|c|c|c|c|c|c|c|c|c|c|c|c|c|c|c|}
\hline \multirow[t]{2}{*}{ İşletme İsmi } & \multicolumn{5}{|c|}{2015} & \multicolumn{5}{|c|}{2016} & \multicolumn{5}{|c|}{2017} \\
\hline & $\begin{array}{l}\text { Net } \\
\text { Kar } \\
\text { Marj1 } \\
\text { (ROS) }\end{array}$ & $\begin{array}{l}\text { Aktif } \\
\text { Devir } \\
\text { Hızı }\end{array}$ & $\begin{array}{l}\text { Aktif } \\
\text { Karlılı̆g1 } \\
\text { (ROA) }\end{array}$ & $\begin{array}{l}\text { Özsermaye } \\
\text { Çarpanı }\end{array}$ & $\begin{array}{l}\text { Özsermaye } \\
\text { Karlı1ı̆ı } \\
\text { (ROE) }\end{array}$ & $\begin{array}{l}\text { Net } \\
\text { Kar } \\
\text { Marj1 } \\
\text { (ROS) }\end{array}$ & $\begin{array}{l}\text { Aktif } \\
\text { Devir } \\
\text { Hizi }\end{array}$ & $\begin{array}{l}\text { Aktif } \\
\text { Karll1lı̆1 } \\
\text { (ROA) }\end{array}$ & $\begin{array}{l}\text { Özsemaye } \\
\text { Çarpanı }\end{array}$ & $\begin{array}{l}\text { Özsermaye } \\
\text { Karlılığ1 } \\
\text { (ROE) }\end{array}$ & $\begin{array}{l}\text { Net } \\
\text { Kar } \\
\text { Marj1 } \\
\text { (ROS) }\end{array}$ & $\begin{array}{l}\text { Aktif } \\
\text { Devir } \\
\text { Hızı }\end{array}$ & $\begin{array}{l}\text { Aktif } \\
\text { Karlılığ1 } \\
\text { (ROA) }\end{array}$ & $\begin{array}{l}\text { Özsermaye } \\
\text { Çarpani }\end{array}$ & $\begin{array}{l}\text { Özserma } \\
\text { ye } \\
\text { Karlılı̆g } 1 \\
\text { (ROE) }\end{array}$ \\
\hline $\begin{array}{l}\text { Acıselsan Acıpayam } \\
\text { Selüloz Sanayi ve Ticaret }\end{array}$ & 0,09 & 0,75 & 0,06 & 1,22 & 0,08 & 0,05 & 0,60 & 0,03 & 1,10 & 0,03 & 0,09 & 0,75 & 0,06 & 1,22 & 0,08 \\
\hline $\begin{array}{l}\text { Aksa Akrilik Kimya } \\
\text { Sanayi A.Ş. }\end{array}$ & 0,1 & 0,9 & 0,09 & 1,81 & 0,16 & 0,06 & 0,74 & 0,05 & 2,11 & 0,10 & 0,11 & 0,83 & 0,09 & 2,44 & 0,21 \\
\hline Alkim Alkali Kimya A.Ș. & 0,12 & 0,93 & 0,11 & 1,32 & 0,14 & 0,16 & 0,86 & 0,13 & 1,42 & 0,19 & 0,16 & 1,01 & 0,16 & 1,36 & 0,22 \\
\hline $\begin{array}{l}\text { Atlantik Petrol Ürünleri } \\
\text { Ticaret ve Sanayi A.SS. }\end{array}$ & 0,00 & 0,79 & 0,00 & 2,00 & 0,00 & $-0,04$ & 0,54 & $-0,02$ & 2,50 & $-0,05$ & $-0,16$ & 0,47 & $-0,07$ & 3,71 & $-0,28$ \\
\hline Aygaz A.Ș. & 0,07 & 1,64 & 0,11 & 1,5 & 0,16 & 0,06 & 1,56 & 0,10 & 1,57 & 0,15 & 0,07 & 1,71 & 0,12 & 1,7 & 0,2 \\
\hline $\begin{array}{l}\text { Bagfaş Bandırma Gübre } \\
\text { Fabrikaları A.Ș. }\end{array}$ & 0,51 & 0,39 & 0,2 & 2,24 & 0,45 & $-0,08$ & 0,43 & $-0,03$ & 2,37 & $-0,08$ & $-0,02$ & 0,42 & $-0,01$ & 2,61 & $-0,02$ \\
\hline $\begin{array}{l}\text { Berkosan Yalıtım ve } \\
\text { Tecrit Maddeleri Üretim } \\
\text { ve Ticaret A.S. . }\end{array}$ & 0,01 & 0,88 & 0,01 & 2,53 & 0,02 & 0,01 & 0,96 & 0,01 & 2,20 & 0,02 & 0,03 & 1,1 & 0,03 & 2,26 & 0,08 \\
\hline $\begin{array}{l}\text { Brisa Bridgestone } \\
\text { Sabancı Lastik Snayai ve } \\
\text { Ticaret A.Ş. }\end{array}$ & 0,11 & 0,85 & 0,09 & 3,28 & 0,3 & 0,05 & 0,62 & 0,03 & 4,97 & 0,14 & 0,04 & 0,66 & 0,03 & 5,05 & 0,14 \\
\hline Deva Holding A.S. & 0,08 & 0,58 & 0,05 & 2,19 & 0,11 & 0,09 & 0,68 & 0,06 & 1,98 & 0,12 & 0,12 & 0,64 & 0,07 & 2,08 & 0,15 \\
\hline $\begin{array}{l}\text { Dyo Boya Fabrikaları } \\
\text { Sanayi ve Ticaret A.Ş. }\end{array}$ & 0,00 & 1,02 & 0,00 & 6,16 & 0,03 & 0,01 & 0,99 & 0,01 & 6,50 & 0,10 & 0 & 1 & 0 & 6,18 & $-0,02$ \\
\hline Ege Gübre Sanayi A.Ș. & 0,01 & 0,89 & 0,01 & 2,30 & 0,02 & 0,07 & 1,26 & 0,08 & 1,79 & 0,15 & 0,09 & 1,25 & 0,12 & 1,58 & 0,18 \\
\hline $\begin{array}{l}\text { Ege Profil Ticaret ve } \\
\text { Sanayi A.Ş. }\end{array}$ & 0,06 & 0,85 & 0,05 & 2,53 & 0,13 & 0,09 & 0,85 & 0,07 & 2,92 & 0,22 & 0,07 & 0,88 & 0,06 & 2,96 & 0,19 \\
\hline $\begin{array}{l}\text { Egeplast Ege Plastik } \\
\text { Ticaret ve Sanayi AŞ. }\end{array}$ & 0,03 & 1,5 & 0,05 & $-3,90$ & $-0,18$ & 0,07 & 1,42 & 0,09 & $-9,41$ & $-0,88$ & 0,11 & 1,46 & 0,16 & 13,81 & 2,16 \\
\hline $\begin{array}{l}\text { Gediz Ambalaj Sanayi ve } \\
\text { Ticaret A.Ș. }\end{array}$ & 0,04 & 0,54 & 0,02 & 1,23 & 0,03 & 0,10 & 0,57 & 0,05 & 1,25 & 0,07 & 0,14 & 0,68 & 0,09 & 1,33 & 0,12 \\
\hline Goodyear Lastikleri $\mathrm{T}$. & 0,06 & 1,58 & 0,09 & 1,71 & 0,15 & 0,03 & 1,67 & 0,06 & 1,77 & 0,10 & 0,06 & 1,68 & 0,09 & 1,99 & 0,19 \\
\hline Gübre Fabrikaları T.A.Ș. & 0,03 & 0,81 & 0,02 & 2,25 & 0,06 & $-0,02$ & 0,84 & $-0,01$ & 2,82 & $-0,04$ & 0,01 & 0,94 & 0,01 & 3,06 & 0,03 \\
\hline Hektaş Ticaret T.A.S.. & 0,15 & 0,86 & 0,13 & 1,61 & 0,21 & 0,17 & 0,86 & 0,14 & 1,66 & 0,24 & 0,2 & 0,78 & 0,15 & 2,26 & 0,34 \\
\hline & & & & & & & & & & & & & & & \\
\hline
\end{tabular}


The Journal of Accounting and Finance- July/2019

(83): $61-84$

\begin{tabular}{|c|c|c|c|c|c|c|c|c|c|c|c|c|c|c|c|}
\hline $\begin{array}{l}\text { Izmir Furça Sanayi ve } \\
\text { Ticaret A.Ş. }\end{array}$ & 0,03 & 0,47 & 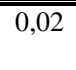 & $1,1,83$ & 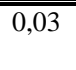 & 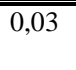 & 0,56 & 0,02 & 2,02 & $\overline{0,03}$ & 0,02 & 0,62 & $\bar{~} 0,01$ & 2,32 & $\overline{0,03}$ \\
\hline $\begin{array}{l}\text { Marshall Boya ve Vernik } \\
\text { Sanayi A.Ş. }\end{array}$ & 0,00 & 1,48 & 0,00 & 1,63 & 0,00 & 0,01 & 1,57 & 0,02 & 1,59 & 0,03 & $-0,01$ & 1,47 & $-0,01$ & 2,12 & $-0,02$ \\
\hline $\begin{array}{l}\text { Mega Polietilen Köpük } \\
\text { Sanayi A.Ş. }\end{array}$ & 0,17 & 0,81 & 0,14 & 1,21 & 0,16 & 0,02 & 0,86 & 0,02 & 1,14 & 0,02 & 0,13 & 0,98 & 0,13 & 1,16 & 0,15 \\
\hline $\begin{array}{l}\text { Özerden Plastik Sanayi ve } \\
\text { Ticaret A.Ş. }\end{array}$ & 0,14 & 1,05 & 0,14 & 1,48 & 0,21 & 0,06 & 1,20 & 0,07 & 1,48 & 0,10 & 0,06 & 1,12 & 0,07 & 1,7 & 0,11 \\
\hline $\begin{array}{l}\text { Petkim Petrokimya } \\
\text { Holding A.Ş. }\end{array}$ & 0,14 & 0,83 & 0,12 & 1,95 & 0,23 & 0,16 & 0,72 & 0,12 & 2,04 & 0,24 & 0,19 & 0,95 & 0,18 & 2,02 & 0,36 \\
\hline $\begin{array}{l}\text { Politeknik Metal Sanayi } \\
\text { ve Ticaret A.S.. }\end{array}$ & 0,2 & 1,62 & 0,32 & 1,33 & 0,43 & 0,18 & 1,37 & 0,24 & 1,45 & 0,35 & 0,18 & 1,35 & 0,24 & 1,37 & 0,33 \\
\hline $\begin{array}{l}\text { RTA Laboratuvarları } \\
\text { Biyolojik Ürünler İlaç ve } \\
\text { Makina Sanayi Ticaret }\end{array}$ & 0,23 & 0,56 & 0,13 & 1,34 & 0,17 & 0,13 & 0,52 & 0,07 & 1,21 & 0,08 & 0,11 & 0,61 & 0,07 & 1,16 & 0,08 \\
\hline $\begin{array}{l}\text { Sanifoam Sünger Sanayi } \\
\text { ve Ticaret A.Ş. }\end{array}$ & $-0,12$ & 0,79 & $-0,1$ & 3,67 & $-0,36$ & $-0,02$ & 0,87 & $-0,02$ & 3,77 & $-0,08$ & 0,01 & 0,92 & 0,01 & 4,11 & 0,05 \\
\hline Sasa Polyester Sanayi & 0,06 & 1,59 & 0,10 & 1,79 & 0,18 & 0,12 & 1,15 & 0,13 & 1,95 & 0,26 & 0,12 & 0,7 & 0,09 & 2,09 & 0,18 \\
\hline $\begin{array}{l}\text { Sekuro Plastik Ambalaj } \\
\text { Sanayi A.Ş. }\end{array}$ & $-0,09$ & 0,91 & $-0,08$ & 3,30 & $-0,27$ & 0,01 & 1,03 & 0,01 & 3,93 & 0,05 & 0,04 & 0,97 & 0,04 & 2,78 & 0,11 \\
\hline Seyitler Kimya Sanayi & 0,13 & 0,72 & 0,09 & 1,18 & 0,11 & 0,18 & 0,61 & 0,11 & 1,38 & 0,16 & 0,11 & 0,75 & 0,08 & 1,12 & 0,09 \\
\hline Soda Sanayi A.Ş. & 0,25 & 0,63 & 0,15 & 1,29 & 0,20 & 0,29 & 0,60 & 0,17 & 1,27 & 0,22 & 0,27 & 0,63 & 0,17 & 1,22 & 0,21 \\
\hline Sodaş Sodyum Sanayi & 0,10 & 0,75 & 0,07 & 1,20 & 0,09 & 0,14 & 0,81 & 0,11 & 1,25 & 0,14 & 0,15 & 0,83 & 0,13 & 1,25 & 0,16 \\
\hline $\begin{array}{l}\text { Temapol Polimer Plastik } \\
\text { ve İnşaat Sanayi Ticaret }\end{array}$ & 0,04 & 0,86 & 0,04 & 2,98 & 0,11 & 0,00 & 0,77 & 0,00 & 3,92 & 0,01 & 0,02 & 0,89 & 0,02 & 4,29 & 0,09 \\
\hline $\begin{array}{l}\text { Tüpraş - Türkiye Petrol } \\
\text { Rafineleri A.Ș. }\end{array}$ & 0,07 & 1,45 & 0,10 & 3,04 & 0,30 & 0,05 & 1,12 & 0,06 & 3,82 & 0,22 & 0,07 & 1,41 & 0,1 & 3,64 & 0,36 \\
\hline
\end{tabular}


Tablo 6. Taş ve Topră̆a Dayalı İmalat Alanında Faaliyet Gösteren İşletmelerin 2015-2016-2017 Yılları Dupont Analizi

\begin{tabular}{|c|c|c|c|c|c|c|c|c|c|c|c|c|c|c|c|}
\hline \multirow[t]{2}{*}{ İşletme İsmi } & \multicolumn{5}{|c|}{2015} & \multicolumn{5}{|c|}{2016} & \multicolumn{5}{|c|}{2017} \\
\hline & $\begin{array}{l}\text { Net } \\
\text { Kar } \\
\text { Marj1 } \\
\text { (ROS) }\end{array}$ & $\begin{array}{l}\text { Aktif } \\
\text { Devir } \\
\text { Hizi }\end{array}$ & $\begin{array}{l}\text { Aktif } \\
\text { Karlılı̆ğ } \\
\text { (ROA) }\end{array}$ & $\begin{array}{l}\text { Özsermaye } \\
\text { Çarpanı }\end{array}$ & $\begin{array}{l}\text { Özsermaye } \\
\text { Karlılı̆ı } \\
\text { (ROE) }\end{array}$ & $\begin{array}{l}\text { Net } \\
\text { Kar } \\
\text { Marj1 } \\
\text { (ROS) }\end{array}$ & $\begin{array}{l}\text { Aktif } \\
\text { Devir } \\
\text { Hızı }\end{array}$ & $\begin{array}{l}\text { Aktif } \\
\text { Karlılığ1 } \\
\text { (ROA) }\end{array}$ & $\begin{array}{l}\text { Özsemaye } \\
\text { Çarpanı }\end{array}$ & $\begin{array}{l}\text { Özsermaye } \\
\text { Karlı1ı̆ı } \\
\text { (ROE) }\end{array}$ & $\begin{array}{l}\text { Net } \\
\text { Kar } \\
\text { Marj1 } \\
\text { (ROS) }\end{array}$ & $\begin{array}{l}\text { Aktif } \\
\text { Devir } \\
\text { Hız1 }\end{array}$ & $\begin{array}{l}\text { Aktif } \\
\text { Karlılığ } 1 \\
\text { (ROA) }\end{array}$ & $\begin{array}{l}\text { Özsermaye } \\
\text { Çarpani }\end{array}$ & $\begin{array}{l}\text { Özsermaye } \\
\text { Karlılığ1 } \\
\text { (ROE) }\end{array}$ \\
\hline Adana Cimento Sanayi T. & 0,34 & 0,48 & 0,16 & 1,11 & 0,18 & 0,34 & 0,41 & 0,14 & 1,20 & 0,17 & 0,31 & 0,08 & 0,03 & 1,53 & 0,04 \\
\hline Afyon Çimento Sanayi T. & 0,22 & 0,17 & 0,04 & 2,26 & 0,09 & 0,16 & 0,10 & 0,02 & 3,37 & 0,05 & $-0,54$ & 0,01 & $-0,01$ & 3,45 & $-0,02$ \\
\hline $\begin{array}{l}\text { Akçansa Çimento Sanayi } \\
\text { ve Ticaret A.Ş. }\end{array}$ & 0,19 & 0,86 & 0,16 & 1,42 & 0,23 & 0,20 & 0,79 & 0,16 & 1,50 & 0,23 & 0,1 & 0,79 & 0,08 & 1,73 & 0,13 \\
\hline Anadolu Cam Sanayi A.Ș. & 0,03 & 0,41 & 0,01 & 2,15 & 0,03 & 0,25 & 0,41 & 0,10 & 2,31 & 0,24 & 0,08 & 0,58 & 0,04 & 2,21 & 0,1 \\
\hline Aslan Çimento A.S.S. & 0,19 & 0,63 & 0,12 & 1,57 & 0,19 & 0,18 & 0,59 & 0,10 & 1,82 & 0,19 & 0,13 & 0,57 & 0,07 & 1,85 & 0,13 \\
\hline $\begin{array}{l}\text { Baștaş Başkent Çimento } \\
\text { Ticaret ve Sanayi A.Ş. }\end{array}$ & 0,14 & 0,65 & 0,09 & 1,26 & 0,12 & 0,13 & 0,73 & 0,09 & 1,30 & 0,12 & 0,08 & 0,78 & 0,06 & 1,44 & 0,09 \\
\hline $\begin{array}{l}\text { Batıçim Batı Anadolu } \\
\text { Çimento Sanayi A.Ş. }\end{array}$ & 0,11 & 0,53 & 0,06 & 1,83 & 0,10 & 0,01 & 0,39 & 0,00 & 2,48 & 0,01 & $-0,03$ & 0,31 & $-0,01$ & 2,27 & $-0,02$ \\
\hline $\begin{array}{l}\text { Batisöke Söke Çimanto } \\
\text { Sanayi A.Ş. }\end{array}$ & 0,15 & 0,29 & 0,05 & 1,85 & 0,08 & $-0,14$ & 0,18 & $-0,03$ & 3,02 & $-0,08$ & $-0,24$ & 0,12 & $-0,03$ & 2,47 & $-0,07$ \\
\hline Bolu Çimento Sanayi & 0,26 & 0,66 & 0,17 & 1,50 & 0,26 & 0,24 & 0,71 & 0,17 & 1,50 & 0,25 & 0,22 & 0,69 & 0,15 & 1,73 & 0,26 \\
\hline Bursa Cimento Fabrikası & 0,08 & 0,99 & 0,08 & 1,47 & 0,12 & 0,11 & 1,00 & 0,11 & 1,44 & 0,15 & 0,08 & 1,06 & 0,08 & 1,56 & 0,13 \\
\hline $\begin{array}{l}\text { Çimbeton Hazırbeton ve } \\
\text { Prefabrik Yapı Elemanları } \\
\text { Sanayi ve Ticaret A.Ş. }\end{array}$ & 0,01 & 1,87 & 0,02 & 2,02 & 0,04 & $\begin{array}{l}-0,02 \\
\end{array}$ & 2,15 & $-0,04$ & 2,55 & $-0,10$ & 0 & 1,62 & 0,01 & 3 & 0,02 \\
\hline $\begin{array}{l}\text { Çimentaş İzmir Çimento } \\
\text { Fabrikası T. A.Ș. }\end{array}$ & 0,10 & 0,49 & 0,05 & 1,28 & 0,06 & $-0,03$ & 0,52 & $-0,02$ & 1,28 & $-0,02$ & 0,04 & 0,55 & 0,02 & 1,33 & 0,03 \\
\hline $\begin{array}{l}\text { Çimsa Çimento Sanayi ve } \\
\text { Ticaret A.Ş. }\end{array}$ & 0,21 & 0,59 & 0,12 & 1,53 & 0,19 & 0,21 & 0,46 & 0,10 & 1,87 & 0,18 & 0,15 & 0,46 & 0,07 & 2,28 & 0,16 \\
\hline $\begin{array}{l}\text { Denizli Cam Sanayi ve } \\
\text { Ticaret A.Ş. }\end{array}$ & 0,03 & 0,86 & 0,02 & 1,38 & 0,03 & $-0,14$ & 0,66 & $-0,09$ & 1,77 & $-0,16$ & $-0,03$ & 0,89 & $-0,03$ & 1,87 & $-0,05$ \\
\hline $\begin{array}{l}\text { Doğusan Boru Sanayi ve } \\
\text { Ticaret A.Ş. }\end{array}$ & $-0,76$ & 0,11 & $-0,08$ & 1,45 & $-0,12$ & $\begin{array}{l}-0,41 \\
\end{array}$ & 0,15 & $-0,06$ & 1,55 & $\begin{array}{l}-0,10 \\
\end{array}$ & $\begin{array}{l}-0,34 \\
\end{array}$ & 0,17 & $-0,06$ & 1,78 & \begin{tabular}{l|l}
$-0,1$ \\
\end{tabular} \\
\hline $\begin{array}{l}\text { Ege Seramik Sanayi ve } \\
\text { Ticaret A.Ş. }\end{array}$ & 0,16 & 0,89 & 0,14 & 1,70 & 0,24 & 0,09 & 0,86 & 0,08 & 1,58 & 0,12 & 0,12 & 0,91 & 0,11 & 1,48 & 0,17 \\
\hline $\begin{array}{l}\text { Göltaş Göller Bölgesi } \\
\text { Çimento Sanayi ve Ticaret }\end{array}$ & 0,03 & 0,56 & 0,02 & 2,17 & 0,03 & 0,03 & 0,46 & 0,01 & 2,34 & 0,03 & 0,02 & 0,49 & 0,01 & 2,52 & 0,03 \\
\hline
\end{tabular}


The Journal of Accounting and Finance- July/2019

(83): 61-84

\begin{tabular}{|c|c|c|c|c|c|c|c|c|c|c|c|c|c|c|c|}
\hline İzocam Ticaret ve Sanayi & 0,07 & 1,49 & 0,11 & 1,60 & 0,18 & 0,05 & 1,31 & 0,07 & 1,83 & 0,13 & 0,04 & 1,38 & 0,05 & 1,86 & 0,1 \\
\hline Konya Çimento Sanayi & 0,14 & 0,77 & 0,11 & 1,19 & 0,13 & 0,15 & 0,67 & 0,10 & 1,22 & 0,12 & 0,12 & 0,78 & 0,1 & 1,25 & 0,12 \\
\hline Kütahya Porselen Sanayi & 0,09 & 0,89 & 0,08 & 1,37 & 0,12 & 0,11 & 0,94 & 0,11 & 1,32 & 0,14 & 0,09 & 0,89 & 0,08 & 1,42 & 0,11 \\
\hline $\begin{array}{l}\text { Mardin Çimento Sanayi } \\
\text { ve Ticaret A.Ş. }\end{array}$ & 0,29 & 0,53 & 0,15 & 1,22 & 0,18 & 0,27 & 0,50 & 0,14 & 1,16 & 0,16 & 0,27 & 0,59 & 0,16 & 1,23 & 0,19 \\
\hline $\begin{array}{l}\text { Niğbaş Niğde Beton } \\
\text { Sanayi ve Ticaret A.Ş. }\end{array}$ & 0,10 & 0,35 & 0,03 & 1,54 & 0,05 & $-0,12$ & 0,46 & $-0,05$ & 1,75 & $-0,09$ & $-0,12$ & 0,51 & $-0,06$ & 2,07 & $-0,13$ \\
\hline Nuh Çimento Sanayi A.Ş. & 0,18 & 0,70 & 0,12 & 1,34 & 0,16 & 0,19 & 0,64 & 0,12 & 1,30 & 0,16 & 0,15 & 0,57 & 0,09 & 1,56 & 0,13 \\
\hline Trakya Cam Sanayi A.Ş. & 0,08 & 0,38 & 0,03 & 1,79 & 0,05 & 0,18 & 0,44 & 0,08 & 1,92 & 0,15 & 0,14 & 0,54 & 0,08 & 1,84 & 0,14 \\
\hline Uşak Seramik Sanayi A.Ş. & 0,01 & 0,51 & 0,00 & 3,94 & 0,01 & 0,02 & 0,49 & 0,01 & 3,83 & 0,04 & 0,02 & 0,54 & 0,01 & 4,15 & 0,04 \\
\hline $\begin{array}{l}\text { Ünye Çimento Sanayi ve } \\
\text { Ticaret A.Ş. }\end{array}$ & 0,22 & 0,69 & 0,15 & 1,15 & 0,17 & 0,23 & 0,75 & 0,17 & 1,17 & 0,21 & 0,31 & 0,66 & 0,2 & 1,26 & 0,25 \\
\hline $\begin{array}{l}\text { Yibitaş Yozgat İşçi Birliği } \\
\text { İnşaat Malzemeleri } \\
\text { Ticaret ve Sanayi A.Ş. }\end{array}$ & 0,25 & 0,67 & 0,17 & 1,28 & 0,21 & 0,27 & $\begin{array}{l}0,60 \\
\end{array}$ & 0,16 & 1,19 & 0,19 & 0,11 & 0,5 & 0,06 & 1,37 & 0,08 \\
\hline
\end{tabular}


Tablo 7: Metal Ana Sanayi İmalatı Alanında Faaliyet Gösteren İşletmelerin 2015-2016-2017 Yılları Dupont Analizi

\begin{tabular}{|c|c|c|c|c|c|c|c|c|c|c|c|c|c|c|c|}
\hline \multirow[t]{2}{*}{ İşletme İsmi } & \multicolumn{5}{|c|}{2015} & \multicolumn{5}{|c|}{2016} & \multicolumn{5}{|c|}{2017} \\
\hline & $\begin{array}{l}\text { Net } \\
\text { Kar } \\
\text { Marj1 } \\
\text { (ROS) }\end{array}$ & $\begin{array}{l}\text { Aktif } \\
\text { Devir } \\
\text { Hızı }\end{array}$ & $\begin{array}{l}\text { Aktif } \\
\text { Karlılı̆ı } \\
\text { (ROA) }\end{array}$ & $\begin{array}{l}\text { Özserma } \\
\text { ye } \\
\text { Çarpanı }\end{array}$ & $\begin{array}{l}\text { Özsermaye } \\
\text { Karlı11ı̆ı } \\
\text { (ROE) }\end{array}$ & $\begin{array}{l}\text { Net Kar } \\
\text { Marj1 } \\
\text { (ROS) }\end{array}$ & $\begin{array}{l}\text { Aktif } \\
\text { Devir } \\
\text { Hızı }\end{array}$ & $\begin{array}{l}\text { Aktif } \\
\text { Karlılı̆g } \\
\text { (ROA) }\end{array}$ & $\begin{array}{l}\text { Özsemaye } \\
\text { Çarpanı }\end{array}$ & $\begin{array}{l}\text { Özsermaye } \\
\text { Karlı11ı̆ } \\
\text { (ROE) }\end{array}$ & $\begin{array}{l}\text { Net } \\
\text { Kar } \\
\text { Marj1 } \\
\text { (ROS) }\end{array}$ & $\begin{array}{l}\text { Aktif } \\
\text { Devir } \\
\text { Hızı }\end{array}$ & $\begin{array}{l}\text { Aktif } \\
\text { Karlılığ } \\
\text { (ROA) }\end{array}$ & $\begin{array}{l}\text { Özsermaye } \\
\text { Çarpani }\end{array}$ & $\begin{array}{l}\text { Özsermaye } \\
\text { Karlılı̆̆1 } \\
\text { (ROE) }\end{array}$ \\
\hline Borusan Mannesmann Boru & $\begin{array}{l}0,01 \\
\text { Sanayi ve }\end{array}$ & \begin{tabular}{|c|}
0,62 \\
Ticaret A.S
\end{tabular} & 0,01 & 2,52 & 0,02 & 0,05 & 0,55 & 0,03 & 2,21 & 0,06 & 0,09 & 0,68 & 0,06 & 2,28 & 0,13 \\
\hline $\begin{array}{l}\text { Burçelik Bursa Çelik } \\
\text { Döküm Sanayii }\end{array}$ & $-0,08$ & 0,50 & $-0,04$ & 1,75 & $-0,07$ & $-0,02$ & 0,57 & $-0,01$ & 1,90 & $-0,02$ & $-0,06$ & 0,62 & $-0,04$ & 2,22 & $-0,09$ \\
\hline $\begin{array}{l}\text { Burçelik Vana Sanayi ve } \\
\text { Ticaret A.Ş. }\end{array}$ & 0,02 & 0,70 & 0,01 & 2,42 & 0,03 & $-0,03$ & 0,57 & $-0,02$ & 2,82 & $-0,05$ & 0,06 & 1,07 & 0,06 & 2,89 & 0,18 \\
\hline Celik Halat ve Tel Sanayii & 0,00 & 1,35 & 0,01 & 3,25 & 0,02 & 0,01 & 1,21 & 0,02 & 3,75 & 0,06 & 0,05 & 1,5 & 0,07 & 3,53 & 0,25 \\
\hline Cemaş Döküm Sanayi A.SS. & $-0,17$ & 0,28 & $-0,05$ & 1,64 & $-0,08$ & $-0,21$ & 0,34 & $-0,07$ & 1,81 & $-0,13$ & $-0,24$ & 0,5 & $-0,12$ & 3,04 & $-0,36$ \\
\hline $\begin{array}{l}\text { Çemtaş Çelik Makina } \\
\text { Sanayi ve Ticaret }\end{array}$ & 0,03 & 1,07 & 0,03 & 1,30 & 0,04 & 0,10 & 1,01 & 0,10 & 1,40 & 0,14 & 0,2 & 1,02 & 0,2 & 1,55 & 0,31 \\
\hline $\begin{array}{l}\text { Çuhadaroğlu Metal Sanayi } \\
\text { ve Pazarlama A.Ş. }\end{array}$ & 0,09 & 1,23 & 0,11 & 1,45 & 0,17 & 0,15 & 0,75 & 0,11 & 1,63 & 0,19 & 0,04 & 0,98 & 0,04 & 1,65 & 0,07 \\
\hline $\begin{array}{l}\text { Demisaş Döküm Emaye } \\
\text { Mamulleri Sanayi A.Ş. }\end{array}$ & 0,03 & 1,02 & 0,03 & 2,41 & 0,07 & $-0,08$ & 0,94 & $-0,07$ & 3,61 & $-0,26$ & 0,02 & 1,19 & 0,02 & 3,76 & 0,09 \\
\hline $\begin{array}{l}\text { Döktaş Dökümcülük } \\
\text { Ticaret ve Sanayi }\end{array}$ & 0,03 & 0,72 & 0,02 & 2,92 & 0,06 & $-0,04$ & 0,79 & $-0,04$ & 24,42 & $-0,86$ & 0,06 & 1,02 & 0,06 & 22,01 & 1,43 \\
\hline $\begin{array}{l}\text { Erbosan Erciyas Boru } \\
\text { Sanayii ve Ticaret }\end{array}$ & 0,07 & 0,11 & 0,09 & 1,44 & 0,13 & 0,13 & 1,01 & 0,13 & 1,45 & 0,19 & 0,14 & 1,07 & 0,15 & 1,6 & 0,24 \\
\hline $\begin{array}{l}\text { Ereğli Demir Çelik } \\
\text { Fabrikaları T.A.Ş. }\end{array}$ & 0,09 & 0,64 & 0,06 & 1,49 & 0,09 & 0,39 & 0,16 & 0,06 & 1,51 & 0,10 & 0,2 & 0,66 & 0,13 & 1,48 & 0,2 \\
\hline İskenderun Demir ve Celik & 0,10 & 0,67 & 0,06 & 1,34 & 0,09 & 0,15 & 0,11 & 0,08 & 0,54 & 1,41 & 0,22 & 0,77 & 0,17 & 1,39 & 0,24 \\
\hline İzmir Demir Çelik Sanayi & $-0,09$ & 1,00 & $-0,09$ & 7,84 & $-0,69$ & $-0,03$ & 0,76 & $-0,02$ & 4,43 & $-0,11$ & 0,01 & 0,98 & 0 & 4,45 & 0,02 \\
\hline $\begin{array}{l}\text { Kardemir Karabük Demir } \\
\text { Celik Sanayi ve Ticaret }\end{array}$ & $-0,01$ & 0,43 & 0,00 & 2,19 & $-0,01$ & $-0,05$ & 0,41 & $-0,02$ & 2,53 & $-0,06$ & 0,06 & 0,57 & 0,04 & 2,83 & 0,1 \\
\hline $\begin{array}{l}\text { Özbal Celik Boru Sanayi } \\
\text { Ticaret ve Taahhüt A.Ş. }\end{array}$ & $-0,06$ & 1,56 & $-0,10$ & 26,54 & $-2,66$ & $-0,05$ & 1,19 & $-0,06$ & $-64,66$ & 4,04 & $-0,09$ & 1,28 & $-0,11$ & $-7,57$ & 0,86 \\
\hline $\begin{array}{l}\text { Sarkuysan Elektrolitik } \\
\text { Bakır Sanayi ve Ticaret }\end{array}$ & 0,01 & 2,82 & 0,04 & 2,66 & 0,10 & 0,01 & 2,61 & 0,03 & 2,93 & 0,08 & 0,02 & 2,89 & 0,06 & 3,33 & 0,19 \\
\hline $\begin{array}{l}\text { Tuğçelik Alüminyum ve } \\
\text { Metal Mamülleri Sanayi ve } \\
\text { Ticaret A.Ş. }\end{array}$ & 0,02 & 0,42 & 0,01 & 3,86 & 0,04 & 0,14 & 0,54 & 0,08 & 2,39 & 0,18 & 0,03 & 0,61 & 0,02 & 2,11 & 0,04 \\
\hline
\end{tabular}


The Journal of Accounting and Finance- July/2019

(83): $61-84$

Tablo 8. Metal Eşya, Makine ve Gereç Yapımı Alanında Faaliyet Gösteren İşletmelerin 2015-2016-2017 Yılları Dupont Analizi

\begin{tabular}{|c|c|c|c|c|c|c|c|c|c|c|c|c|c|c|c|}
\hline \multirow[t]{2}{*}{ İşletme İsmi } & \multicolumn{5}{|c|}{2015} & \multicolumn{5}{|c|}{2016} & \multicolumn{5}{|c|}{2017} \\
\hline & $\begin{array}{l}\text { Net } \\
\text { Kar } \\
\text { Marj1 } \\
\text { (ROS) }\end{array}$ & $\begin{array}{l}\text { Aktif } \\
\text { Devir } \\
\text { Hızı }\end{array}$ & $\begin{array}{l}\text { Aktif } \\
\text { Karlılığ } \\
\text { (ROA) }\end{array}$ & $\begin{array}{l}\text { Özsermaye } \\
\text { Çarpanı }\end{array}$ & $\begin{array}{l}\text { Özsermaye } \\
\text { Karlılığı } \\
\text { (ROE) }\end{array}$ & $\begin{array}{l}\text { Net } \\
\text { Kar } \\
\text { Marj1 } \\
\text { (ROS) }\end{array}$ & $\begin{array}{l}\text { Aktif } \\
\text { Devir } \\
\text { Hizı }\end{array}$ & $\begin{array}{l}\text { Aktif } \\
\text { Karlılığ } \\
\text { (ROA) }\end{array}$ & $\begin{array}{l}\text { Özsemaye } \\
\text { Çarpanı }\end{array}$ & $\begin{array}{l}\text { Özsermaye } \\
\text { Karlılığı } \\
\text { (ROE) }\end{array}$ & $\begin{array}{l}\text { Net } \\
\text { Kar } \\
\text { Marj1 } \\
\text { (ROS) }\end{array}$ & $\begin{array}{l}\text { Aktif } \\
\text { Devir } \\
\text { Hızı }\end{array}$ & $\begin{array}{l}\text { Aktif } \\
\text { Karlıl1ığ } \\
\text { (ROA) }\end{array}$ & $\begin{array}{l}\text { Özsermaye } \\
\text { Çarpani }\end{array}$ & $\begin{array}{l}\text { Özsermaye } \\
\text { Karlılı̆g } \\
\text { (ROE) }\end{array}$ \\
\hline $\begin{array}{l}\text { Alarko Carrier Sanayi ve } \\
\text { Ticaret A.Ș. }\end{array}$ & 0,08 & 1,02 & 0,09 & 1,23 & 0,11 & 0,08 & 1,10 & 0,09 & 1,29 & 0,11 & 0,09 & 1,23 & 0,11 & 1,3 & 0,14 \\
\hline $\begin{array}{l}\text { Anadolu Isuzu Otomotiv } \\
\text { Sanayi ve Ticaret A.S. }\end{array}$ & 0,02 & 1,06 & 0,02 & 2,73 & 0,05 & $-0,06$ & 0,94 & $-0,05$ & 3,37 & $-0,18$ & $-0,05$ & 0,66 & $-0,03$ & 2,31 & $-0,08$ \\
\hline Arçelik A.Ş. & 0,06 & 1,03 & 0,06 & 2,94 & 0,19 & 0,08 & 0,95 & 0,08 & 2,82 & 0,22 & 0,04 & 1,02 & 0,04 & 2,97 & 0,12 \\
\hline $\begin{array}{l}\text { Ayes Çelik Hasır ve Çit } \\
\text { Sanayi A.Ş. }\end{array}$ & 0,02 & 2,99 & 0,05 & 1,40 & 0,07 & 0,02 & 3,40 & 0,05 & 1,58 & 0,09 & 0,02 & 3,55 & 0,06 & 2,24 & 0,13 \\
\hline $\begin{array}{l}\text { Balatacilar Balatacilık } \\
\text { Sanayi ve Ticaret A.Ş. }\end{array}$ & $-0,05$ & 0,54 & $-0,03$ & 3,54 & $-0,09$ & 0,05 & 0,51 & 0,03 & 4,08 & 0,11 & $-0,04$ & 0,32 & $-0,01$ & 4,76 & $-0,07$ \\
\hline $\begin{array}{l}\text { Bantaş Bandırma Ambalaj } \\
\text { Sanayi Ticaret A.Ş. }\end{array}$ & 0,10 & 0,44 & 0,04 & 1,54 & 0,07 & 0,10 & 0,48 & 0,05 & 1,44 & 0,07 & 0,02 & 0,58 & 0,01 & 1,54 & 0,02 \\
\hline $\begin{array}{l}\text { Bosh Fren Sistemleri } \\
\text { Sanayi ve Ticaret A.Ş. }\end{array}$ & 0,15 & 1,24 & 0,19 & 1,37 & 0,25 & 0,16 & 1,44 & 0,24 & 1,34 & 0,32 & 0,13 & 1,71 & 0,23 & 1,46 & 0,33 \\
\hline $\begin{array}{l}\text { Ditaş Doğan Yedek Parça } \\
\text { İmalat ve Teknik A.Ş. }\end{array}$ & 0,00 & 1,17 & 0,00 & 2,74 & $-0,01$ & $-0,06$ & 1,03 & $-0,06$ & 3,34 & $-0,19$ & 0,05 & 1,12 & 0,06 & 3,79 & 0,23 \\
\hline Ege Endüstri ve Ticaret & 0,33 & 1,14 & 0,37 & 1,37 & 0,51 & 0,39 & 0,77 & 0,30 & 1,29 & 0,38 & 0,38 & 0,8 & 0,31 & 1,25 & 0,38 \\
\hline Emek Elektrik Endüstrisi & 0,03 & 0,47 & 0,01 & 2,44 & 0,04 & 0,04 & 0,47 & 0,02 & 2,69 & 0,05 & $-0,09$ & 04 & $-0,03$ & 3,86 & $-0,13$ \\
\hline $\begin{array}{l}\text { Eminiş Ambalaj Sanayi ve } \\
\text { Ticaret A.Ş. }\end{array}$ & $-0,22$ & 0,85 & $-0,19$ & 21,24 & $-3,93$ & $-0,39$ & 0,66 & $-0,26$ & 8,35 & $-2,16$ & $-0,07$ & 0,91 & $-0,07$ & 12,86 & $-0,84$ \\
\hline $\begin{array}{l}\text { Fedaral-Mogul İzmit } \\
\text { Piston ve Pim Üretim } \\
\text { Tesisleri A.Ş. }\end{array}$ & 0,27 & 1,28 & 0,34 & 1,11 & 0,38 & 0,27 & 1,30 & 0,36 & 1,17 & 0,42 & 0,29 & 1,41 & 0,4 & 1,16 & 0,47 \\
\hline Ford Otomotiv Sanayi & 0,05 & 1,99 & 0,10 & 2,75 & 0,28 & 0,05 & 1,97 & 0,10 & 2,94 & 0,30 & 0,06 & 2,11 & 0,12 & 3,25 & 0,4 \\
\hline $\begin{array}{l}\text { Formet Çelik Kapı Sanayi } \\
\text { ve Ticaret A.Ş. }\end{array}$ & 0,05 & 0,96 & 0,05 & 6,76 & 0,34 & 0,09 & 0,63 & 0,06 & 6,41 & 0,37 & 0,12 & 0,66 & 0,08 & 4,83 & 0,37 \\
\hline $\begin{array}{l}\text { Gersan Elektrik Ticaret } \\
\text { ve Sanayi A.Ş. }\end{array}$ & 0,26 & 0,81 & 0,21 & 1,72 & 0,36 & 0,03 & 0,89 & 0,03 & 1,88 & 0,05 & 0,07 & 0,91 & 0,07 & 1,87 & 0,12 \\
\hline $\begin{array}{l}\text { Ihlas Ev Aletleri İmalat } \\
\text { Sanayi ve Ticaret A.Ş. }\end{array}$ & 0,13 & 0,37 & 0,05 & 1,29 & 0,06 & $-0,01$ & 0,42 & 0,00 & 1,38 & 0,00 & $-0,01$ & 0,54 & 0 & 1,41 & 0 \\
\hline $\begin{array}{l}\text { Jantsa Jant Sanayi ve } \\
\text { Ticaret A.Ş. }\end{array}$ & 0,08 & 0,90 & 0,07 & 1,56 & 0,11 & 0,09 & 0,89 & 0,08 & 1,46 & 0,11 & 0,15 & 1,06 & 0,16 & 1,59 & 0,26 \\
\hline Karsan Otomotiv Sanayi & $-0,06$ & 0,61 & $-0,04$ & 6,90 & $-0,26$ & $-0,01$ & 0,48 & $-0,05$ & 5,01 & $-0,23$ & 0 & 0,11 & 0 & 5,14 & 0 \\
\hline
\end{tabular}


Muhasebe ve Finansman Dergisi - Temmuz/2019

(83): 61-84

\begin{tabular}{|c|c|c|c|c|c|c|c|c|c|c|c|c|c|c|c|}
\hline ve Ticaret A.Ş. & & & & & & & & & & & & & & & \\
\hline $\begin{array}{l}\text { Katmerciler Araç Üstü } \\
\text { Ekipman Sanayi ve } \\
\text { Ticaret A.Ş. }\end{array}$ & 0,06 & 1,36 & 0,08 & 3,65 & 0,30 & 0,07 & 0,49 & 0,03 & 4,06 & 0,13 & 0,07 & 0,34 & 0,02 & 5,67 & 0,13 \\
\hline $\begin{array}{l}\text { Klimasan Klima Sanayi } \\
\text { ve Ticaret A.Ș. }\end{array}$ & 0,08 & 0,67 & 0,05 & 4,32 & 0,24 & 0,12 & 0,62 & 0,07 & 4,14 & 0,3 & 0,03 & 0,66 & 0,02 & 4,4 & 0,1 \\
\hline Makina Takım Endüstrisi & $-0,24$ & 0,28 & $-0,07$ & $-8,74$ & 0,61 & $-0,17$ & 0,41 & $-0,07$ & 2,13 & $-0,15$ & 0,1 & 0,52 & 0,05 & 1,88 & 0,1 \\
\hline $\begin{array}{l}\text { Otokar Otomotiv ve } \\
\text { Savunma Sanayi A.Ș. }\end{array}$ & 0,06 & 0,89 & 0,05 & 6,54 & 0,32 & 0,04 & 0,92 & 0,04 & 7,34 & 0,29 & 0,06 & 0,89 & 0,05 & 7,09 & 0,35 \\
\hline $\begin{array}{l}\text { Parsan Makina Parçaları } \\
\text { Sanayi A.Ş. }\end{array}$ & 0,09 & 0,25 & 0,02 & 1,68 & 0,04 & $-0,02$ & 0,23 & 0,00 & 1,94 & $-0,01$ & 0,03 & 0,25 & 0,01 & 2,11 & 0,02 \\
\hline $\begin{array}{l}\text { Safkar Ege Soğutmacılık } \\
\text { Klima Soğuk Hava } \\
\text { Tesisisleri İhracat İthalat } \\
\text { Sanayi v e Ticaret A.Ş. }\end{array}$ & 0,02 & 1,44 & 0,03 & 3,12 & 0,08 & 0,04 & 1,37 & 0,06 & 2,27 & 0,14 & 0,02 & 1,23 & 0,03 & 1,68 & 0,04 \\
\hline $\begin{array}{l}\text { Silverline Endüstri ve } \\
\text { Ticaret A.Ş. }\end{array}$ & 0,00 & 2,04 & $-0,01$ & 1,99 & $-0,01$ & 0,01 & 1,78 & 0,02 & 2,38 & 0,05 & 0,06 & 2,02 & 0,12 & 2,21 & 0,27 \\
\hline $\begin{array}{l}\text { Tofaş Türk Otomobil } \\
\text { Fabrikası A.Ş. }\end{array}$ & 0,08 & 1,01 & 0,08 & 3,82 & 0,32 & 0,07 & 1,20 & 0,08 & 4,00 & 0,33 & 0,07 & 1,26 & 0,09 & 3,87 & 0,36 \\
\hline $\begin{array}{l}\text { Türmosan Motor ve } \\
\text { Traktör Sanayi A.Ş. }\end{array}$ & 0,07 & 1,27 & 0,10 & 1,35 & 0,13 & 0,08 & 1,14 & 0,09 & 1,44 & 0,13 & $-0,02$ & 1 & $-0,02$ & 1,37 & $-0,03$ \\
\hline $\begin{array}{l}\text { Türk Prysmian Kablo ve } \\
\text { Sistemleri A.Ş. }\end{array}$ & 0,01 & 1,50 & 0,02 & 4,29 & 0,09 & 0,02 & 1,42 & 0,03 & 4,08 & 0,12 & 0,01 & 1,44 & 0,01 & 3,49 & 0,03 \\
\hline $\begin{array}{l}\text { Türk Traktör ve Ziraat } \\
\text { Makineleri A.Ş. }\end{array}$ & 0,08 & 1,54 & 0,13 & 3,10 & 0,39 & 0,11 & 1,50 & 0,16 & 3,29 & 0,53 & 0,08 & 1,51 & 0,12 & 3,68 & 0,42 \\
\hline $\begin{array}{l}\text { Ulusoy Elektrik İmalat } \\
\text { Taahhüt ve Ticaret A.Ş. }\end{array}$ & 0,09 & 0,96 & 0,09 & 1,41 & 0,13 & 0,16 & 1,20 & 0,19 & 1,41 & 0,27 & 0,2 & 1,53 & 0,31 & 1,4 & 0,43 \\
\hline $\begin{array}{l}\text { Vestel Beyaz Eşya Sanayi } \\
\text { ve Ticaret A.S. }\end{array}$ & 0,06 & 1,47 & 0,10 & 2,41 & 0,23 & 0,11 & 1,33 & 0,14 & 2,49 & 0,35 & 0,08 & 1,27 & 0,1 & 2,99 & 0,29 \\
\hline $\begin{array}{l}\text { Vestel Elektronik Sanayi } \\
\text { ve Ticaret A.Ş. }\end{array}$ & 0,01 & 0,99 & 0,01 & 5,93 & 0,04 & 0,02 & 0,99 & 0,02 & 5,25 & 0,09 & 0 & 0,87 & 0 & 6,08 & 0,02 \\
\hline
\end{tabular}




\section{The Journal of Accounting and Finance- July/2019}

(83): 61-84

Tablo 9. Diğer İmalat Sanayi Alanında Faaliyet Gösteren İşletmelerin 2015-2016-2017 Y1lları Dupont Analizi

\begin{tabular}{|c|c|c|c|c|c|c|c|c|c|c|c|c|c|c|c|}
\hline \multirow[t]{2}{*}{ İşletme İsmi } & \multicolumn{5}{|l|}{2015} & \multicolumn{5}{|l|}{2016} & \multicolumn{5}{|l|}{2017} \\
\hline & $\begin{array}{l}\text { Net } \\
\text { Kar } \\
\text { Marj1 } \\
\text { (ROS) }\end{array}$ & $\begin{array}{l}\text { Aktif } \\
\text { Devir } \\
\text { Hızı }\end{array}$ & $\begin{array}{l}\text { Aktif } \\
\text { Karllığg } \\
\text { (ROA) }\end{array}$ & $\begin{array}{l}\text { Özsermaye } \\
\text { Çarpanı }\end{array}$ & $\begin{array}{l}\text { Özsermaye } \\
\text { Karlılığ1 } \\
\text { (ROE) }\end{array}$ & $\begin{array}{l}\text { Net } \\
\text { Kar } \\
\text { Marj1 } \\
\text { (ROS) }\end{array}$ & $\begin{array}{l}\text { Aktif } \\
\text { Devir } \\
\text { Hizi }\end{array}$ & $\begin{array}{l}\text { Aktif } \\
\text { Karll11!ğ1 } \\
\text { (ROA) }\end{array}$ & $\begin{array}{l}\text { Özsemaye } \\
\text { Çarpanı }\end{array}$ & $\begin{array}{l}\text { Özsermaye } \\
\text { Karlılığı } \\
\text { (ROE) }\end{array}$ & $\begin{array}{l}\text { Net } \\
\text { Kar } \\
\text { Marj1 } \\
\text { (ROS) }\end{array}$ & $\begin{array}{l}\text { Aktif } \\
\text { Devir } \\
\text { Hızı }\end{array}$ & $\begin{array}{l}\text { Aktif } \\
\text { Karlılığ1 } \\
\text { (ROA) }\end{array}$ & $\begin{array}{l}\text { Özsermaye } \\
\text { Çarpani }\end{array}$ & $\begin{array}{l}\text { Özsermaye } \\
\text { Karlılı̆̆ } \\
\text { (ROE) }\end{array}$ \\
\hline $\begin{array}{l}\text { Adel Kalemcilik Ticaret } \\
\text { ve Sanayi A.Ş. }\end{array}$ & 0,28 & 0,66 & 0,19 & 1,85 & 0,35 & 0,07 & 0,86 & 0,06 & 1,62 & 0,10 & 0,08 & 0,9 & 008 & 1,73 & 0,13 \\
\hline $\begin{array}{l}\text { Say Reklamcilık Yap1 } \\
\text { Dekorasyon Proje Taahhüt } \\
\text { Sanayi ve Ticaret A.Ș. }\end{array}$ & 0,07 & 0,77 & 0,06 & 3,05 & 0,18 & $-0,16$ & 0,99 & $-0,15$ & 4,02 & $-0,62$ & --- & --- & --- & --- & --- \\
\hline $\begin{array}{l}\text { Serve Kırtasiye Sanayi ve } \\
\text { Ticaret A.Ş. }\end{array}$ & $-1,52$ & 0,03 & $-0,04$ & 1,07 & $-0,04$ & 0,00 & 2,19 & 0,00 & 1,95 & 0,00 & $-0,36$ & 1,49 & $-0,54$ & 3,49 & $-1,89$ \\
\hline
\end{tabular}

